\title{
Küresel İklim Değişikliğinin Yağış ve Sıcaklık Üzerindeki Etkilerinin Kırkgöze Dağlık Havzasındaki Kar Kütlesi Üzerinde 2050 Yılı İçin Beklenen Etkilerinin HSPF Model Programı İle İncelenmesi
}

\author{
Selim Şengül ${ }^{1 *}$ \\ ${ }^{1}$ Atatürk Üniversitesi, Mühendislik Fakültesi, İnşaat Mühendisliği Bölümü, Erzurum, Türkiye, (ORCID: 0000-0002-0041-1454)
}

(İlk Geliş Tarihi 2 Ağustos 2019 ve Kabul Tarihi 5 Kasım 2019)

(DOI: 10.31590 /ejosat.601051)

ATIF/REFERENCE: Şengül, S. (2019). Küresel İklim Değişikliğinin Yağış ve Sıcaklık Üzerindeki Etkilerinin Kırkgöze Dağlık Havzasındaki Kar Kütlesi Üzerinde 2050 Yılı İçin Beklenen Etkilerinin HSPF Model Programı İle İncelenmesi. Avrupa Bilim ve Teknoloji Dergisi, (17), 611-636.

\section{Öz}

Bu çalışmada Kırkgöze Havzası'nın kar birikme ve erime dönemlerindeki hidrolojik davranışını modellemek için kullanılan HSPF model parametreleri güncellenerek kalibre edilmiştir. BASINS programında önceden alansal karakterizasyonu yapılmış olan havzanın HSPF model programı ile havza ve iklim karakterizasyonu yapılarak üç farklı noktada kar birikmesi ve erimesi davranışları modellenmiş ve yağış ve sıcaklık parametrelerinin öngörülen iklim değişikliği trendlerinin bölgedeki karın birikme ve erime süreçleri üzerindeki etkileri simüle edilmiştir. Sicaklık ve yağış, iklim değişikliğinin en önemli göstergeleridir. Özellikle kar yağışından beslenen havzalar için, karların erime döneminin erkene çekilmesi akarsu akımlarını etkiler. Sıcaklık artışı, kar erime dönemlerinin erkene çekilmesine sebep olmakta ve bunun sonucunda akarsuların hidrolojik rejimleri değişmektedir.

Kavramsal yapıdaki karmaşık bir model olan HSPF modeli ile Türkiye'de kar erimesinin etkili olduğu dağlık havzalarda farklı yükseklik ve bakıdaki üç farklı noktada gerçekleştirilen analizler ile Türkiye’nin Doğu Anadolu Bölgesi’ndeki iklim değişikliği sonucu öngörülen yağış ve sıcaklık trendlerinin karın birikmesine ve erimesine olan etkisi 2050 yılı tahminleri ile ortaya konulmuştur. 2011 yılı verileri referans alınarak gelecekteki 40 yıllık periyod için gerçekleştirilen tahminlere göre erime dönemi yüksek rakımlarda kuzey bakıda 15 gün, güney bakıda ise 25 gün kadar öne kayabilmektedir. Çalışmada kar örtüsü üzerine yağan yağmurun ve erken erime sonucu çıplak arazi üzerine yağarak direk akışa geçen yağmurun gözlenen debiler üzerinde önemli etkilerinin olduğu sonucuna varılmıştır. Büyük kar kütlelerinden salınan pik debiler günlük bazda 1.4 kata kadar çıkabilmektedir. Bu ise ilerleyen dönemde bazı lokasyonlarda taşkın debilerinde önemli bir artışa işaret etmektedir. Bu nedenle taşkın koruma yapılarının ekonomik ömürleri boyunca hizmet verebilmesi için küresel iklim değişikliği trendleri gözönünde tutularak boyutlandırılması gerektiği sonucunu doğurmaktadır. Ayrıca karın zamanla daha yüksek kotlarda birikmeye başlayacak olması ile karla kaplı alanların azalacak olması özellikle farklı disiplinlerdeki kış sporlarının yapıldığı Doğu Anadolu'da mevcut bulunan tesislerin geleceğe yönelik projeksiyonlarının yapılması hususunda önem arz etmektedir.

Anahtar Kelimeler: Kar Modellemesi, Enerji ve Kütle Dengesi, HSPF Modeli, Kırkgöze Havzası, İklim Değişikliği, Kış Sporları.

\section{Investigation of the Effects of Global Climate Change on Precipitation and Temperature for the Snowpack in Kırkgöze Mountainous Basin Expected for 2050 with HSPF Model Program}

\begin{abstract}
In this study, HSPF model inputs were re-calibrated to model the Kırkgöze Basin's hydrological behavior in terms of snow accumulation and depletion attitudes. Spatial characterization was defined earlier by using the BASINS program for the application of the HSPF model inputs. By using the HSPF model program, basin and climate characterization were constructed and the effects of climate change
\end{abstract}

\footnotetext{
* Sorumlu Yazar: Atatürk Üniversitesi, Mühendislik Fakültesi, İnşaat Mühendisliği Bölümü, Erzurum, Türkiye (ORCID: 0000-0002-0041-1454), ssengul@atauni.edu.tr
} 
impact based on temperature and precipitation trends investigated upon snow accumulation and depletion simulations at 3 different locations. Temperature and precipitation are the most important indicators of climate change. Especially for the basins fed from snowfall, withdrawing the snow-melting period to earlier times will affect the streamflows. The rise in temperature leads to early snow melting and as a result, the hydrological regimes of the rivers change.

The analysis performed using HSPF such a conceptual model with a complex structure conveniently for the snowmelt dominated mountainous basins in the Eastern Anatolian Region of Turkey at three different stations with various aspects and altitudes. The effects of climate change trends over precipitation and temperature values have been analyzed to determine their impacts on snowpack for the year 2050 in the eastern mountainous regions of Turkey. According to the climate forecasts for the next 40-year period based on the 2011 data, at higher altitudes, the melting period can shift up to 15 days earlier from the snowpacks having the north aspect and 25 days from the south aspects. It was concluded that rain on snow events and the rain falling directly on bare land as a result of early melting had significant effects on observed flow rates. Peak flows released from the highland snowpacks can reach up to 1.4 times at daily scale. At some locations, this indicates a significant increase in flood flow rates for the following period. Flood protection structures should be resized according to global climate change impacts to serve for the future period throughout their economic lives. Besides, snowcovered areas will gradually decrease, as the snow will begin to accumulate at higher elevations, it is important to make future projections of the existing facilities in Eastern Anatolia, where winter sports in different disciplines are still performing.

Keywords: Snowmelt Modeling, Energy and Mass Balance, HSPF Model, Kırkgöze Basin, Climate Change, Winter Sports.

\section{Giriş}

Dünyanın birçok bölgesinde, özellikle dağlık bölgelerde kar erimelerinden meydana gelen akışlar hidrolojik döngünün ve su temininin en önemli elemanlarından biridir. Küresel ısınma sonucunda artan sıcaklık değerleri göz önünde bulundurularak kar kütlesinin ve nihai olarak kar erimelerinin zemin-su etkileşiminin modellenmesi esnasında kar örtüsü üzerine yağan yağmurun etkileri gibi kompleks durumlarla karşılaşılır. Bu nedenle ayrıntılı fiziksel tabanlı kar modellerine ihtiyaç vardır. Bununla birlikte bu tarzda modeller kullanılırken çok sayıda veri girişine ihtiyaç duyulmakta olup genellikle dağlık arazilerdeki koşullar bu tarz verilerin temininde birçok zorluğu da beraberinde getirmektedir (Griessinger et al., 2019). Kar erimelerinden oluşacak akımların tahmini, taşkınların kontrolü, hidroelektrik güç üretimi, tarım, sanayi ve günlük yaşam için su temini, su kuvveti tesisleri, çığ tehlikeleri vb. konularda yapılacak değerlendirmeler için oldukça önem taşımaktadır.

Yağışın kış aylarında kar olarak görüldüğü yüksek yerlerde kar erimesi su kaynaklarının beslenmesi, geliştirilmesi ve işletilmesi için çok önemli rol oynar. Kar erimelerinden meydana gelen akış, özellikle yüksek dağlık alanların hâkim olduğu Doğu Anadolu Bölgesi'nde son derece önemlidir. Dağların yüksek kotlarından kaynaklanan sular üzerine kurulu birçok barajın yıllık su hacimlerinin büyük bir kısmının kış aylarında meydana gelen yağışlardan ve ilkbaharda ise kar erimesinden ve kar örtüsü üzerine düşen yağmurdan kaynaklandığı belirlenmiştir. Bu nedenle kar potansiyelinin oldukça yüksek olduğu Doğu Anadolu Bölgesi'nde yapılacak olan kar hidrolojisi çalışmaları su kaynaklarının planlanması, ekonomik olarak işletilmesi ve bölgedeki tarımsal ve sportif faaliyetlere katkıda bulunmak açısından büyük önem taşımaktadır.

Kar erimesi akışlarının tahmini ve benzetimini yapmak için pek çok yöntem bulunmaktadır. Hidrolojik Simülasyon ProgramıFORTRAN (HSPF) gibi karmaşı modeller, veri analizi ve kuramsal çatıyı bir araya getiren, ileri düzeyde model kalibrasyonuna yönelik araçların kullanımını gerektirmektedir.

ABD Çevre Koruma Kurumu (USEPA) tarafından geliştirilmiş olan BASINS (Better Assessment Science Integrating Point and Non-point Sources) yazılımı çok işlevli havza analizi ve modelleme aracıdır. BASINS, modeller ile verileri birlikte kullanarak su kalitesi ve havza çalışmalarına destek sağlayabilmektedir. HSPF, BASINS sisteminin çekirdeğini oluşturan modellerden biridir. BASINS veri toplama, veri hazırlama, havza karakterizasyonu, model uygulamaları, model çıktılarının yorumlanması ve Coğrafi Bilgi Sistemleri (CBS) yardımı ile sonuçların görselleştirilmesi, haritalandırılması ve tabloların oluşturulması süreçlerini bütünleştirmektedir.

Bu çalışmada BASINS altında çalışan ve hidrolojik simülasyonların gerçekleştirildiği HSPF uygulaması için model girdileri yeniden kalibre edilmiş olup gelecekte beklenen yağış ve sıcaklık trendlerinin kar kütlesi üzerindeki etkisi enerji ve kütle dengesi metodolojisi kullanılarak incelenmiştir.

Modeller kavramsal olarak, parametreleri ölçülebilen ve parametreleri kalibre edilebilen olmak üzere iki sınıfa ayrılmaktadır. Parametreleri ölçülebilen modeller, havzadaki süreçler ve bunların fiziksel anlamları ile kurulup, bilinen havza özelliklerinden hareket edilerek tahmin edilebilen parametreleri kullanmaktadır. Ancak, model uygulamasının kapsamı ve ölçeği arttıkça, model karmaşıklığı da artabilmekte ve buna bağlı olarak gereken parametre sayısı da artmaktadır. Belirsizlik parametrelerinin çoğalması, fiziksel bazlı modellerin havza ölçeğinde uygulanmasını kısıtlamaktadır. Bunun sonucunda havza ölçeğinde parametreleri ölçülebilen modellerin uygulanması zorlaşmaktadır (Al-Abed \& Whiteley, 2002). Parametreleri kalibre edilen modeller ise, fiziksel süreçleri tüm ayrıntıları ile ele alan özgün denklemler yerine, süreçleri genel hatları ile temsil eden denklemleri kullanmaktadır. Bu denklemlerin bünyesindeki ampirik katsayılar deneme-yanılma yöntemi ile belirlenmektedir. Çok sayıda model parametresinin olduğu, bu parametrelerin sayısal büyüklüklerinin fiziksel süreçlere olan etkilerinin doğrudan anlaşılamadığı ve parametrelerin birbirlerinin büyüklüklerini etkiledikleri durumlarda, model kalibrasyonunun başarılı bir şekilde tamamlanması zorlaşmaktadır (Hayashi, Murakami, Watanabe, \& Bao-Hua, 2004). Hidrolojik Simülasyon Programı-FORTRAN (HSPF) kavramsal bir model olup karmaşık yapıdadır. Model parametrelerinin değerlendirilmesinin yanı sıra modelde itici dış güçlerle ilgili verilere ve havzanın fiziksel özelliklerini karakterize eden topoğrafya, zemin özellikleri, arazi kullanımı gibi diğer alansal verilere ihtiyaç duyulmaktadır. Değişik amaçlı çevre verisi analizlerini bir araya getirebilen bütünleşik sistemler, bunun gibi karmaşık yapıdaki modellerin kalibrasyonunda kullanılan temel araçlardır. 
Kar erimesinin etkili olduğu Kırkgöze (Çipak) Havzası çalışma alanında, iklim karakterizasyonunu gerçekleştirebilmek için HSPF model programı kullanılarak hava sıcaklığı, çiğ noktası sıcaklığı, yağış, rüzgâr hızı, potansiyel evapotranspirasyon ve güneş 1şıması (solar radyasyon) zaman serilerinin zamansal ve mekânsal olarak dağılımı yapılmıştır. Bu çalışmada zaman serileri havza sınırları dâhilinde kurulmuş olan ve 15'er dakikalık zaman aralıklarında ölçüm alan 3 adet otomatik meteoroloji ve kar gözlem istasyonundan alınan veriler kullanılarak 1'er saatlik ölçekte hazırlanmıştır.

Türkiye'de ortalama yıllık yağış yüksekliği $643 \mathrm{~mm}$ olup yılda ortalama 501 milyar $\mathrm{m}^{3}$ suya tekabül etmektedir.. Yıllık yüzey akımının 186 milyar $\mathrm{m}^{3} / \mathrm{y}$ ll olduğu ve buna komşu ülkelerden gelen 7 milyar $\mathrm{m}^{3} / \mathrm{yll}^{\prime} \mathrm{l}_{\mathrm{k}} \mathrm{k}$ akım eklendiğinde Türkiye'nin yıllık toplam yüzey akışı 193 milyar m³/yll değerine ulaşmaktadır. Bu potansiyelin \%31'ini ise Türkiye'nin Doğu Anadolu'daki dağlık alanlarından beslenen Firat ve Dicle havzalarından gelen akımlar oluşturmaktadır (DSİ, 2009).

İklim, tüm hidrolojik terimleri etkileyen temel faktör olduğundan, iklimdeki değişiklikler su kaynaklarının miktarını ve kalitesini doğrudan etkilemektedir. Atmosferdeki karbondioksit ve diğer gazların konsantrasyonlarındaki artışın, dünyanın 1Sı dengesini değiştirmesi ve küresel iklim değişikliğine neden olması beklenir. Bu gazlar güneşten gelen güneş radyasyonunun atmosferden geçmesine izin verir, ancak yansıyan ısının uzaya geri dönmesine engel olur. Bu durum, dünyanın sıcaklığının artmasına neden olur.

Gözlemsel kayıtlar ve iklim öngörüleri, tatlı su kaynaklarının savunmasız olduğu ve insan toplulukları ve ekosistemler için geniş kapsamlı sonuçlara yol açacak iklim değişikliği tarafindan şiddetli etkilenme ihtimaline sahip olduğuna dair bol miktarda kanıt sunmaktadır. Dünya tarafindan alınan güneş enerjisinin çoğu, hidrolojik döngüyü sürdürebilmek için kullanıldığından, atmosferde yakalanan daha yüksek güneş enerjisi seviyeleri, yağış yapısının değişmesi ile küresel sıcaklıklarda ve bu döngüde değişikliklere yol açacaktır. Birkaç yıl boyunca gözlemlenen ısınma, atmosferik su buharı içeriğinin arttırılması; yağış yapıları, şiddeti ve uçlarını değiştirmek; azaltılmış kar örtüsü ve buzun geniş çapta erimesi; toprak nemi ve akışındaki değişiklikler gibi büyük ölçekli hidrolojik döngüdeki değişikliklerle ilişkilendirilmiştir (IPCC, 2007).

Dağ kar örtüsü ve ilkbahar akışı, iklim değişkenliği ve değişiminin önemli ve bölgesel olarak bütünleşmiş göstergelerini sundukları için yüzey su kaynakları açısından kritik öneme sahiptir. Dünyanın çeşitli bölgelerinde, nehir akımlarının yıl içindeki değişiminin sıcaklık değişimlerinden ziyade yağış değişimleriyle daha güçlü ilişkili olduğu bulunmuştur. Öte yandan, Avrupa'nın doğu kısımlarında birçok yerde yüzeysel akımların bahar aylarından kış aylarına doğru kayması yalnızca yağış toplamlarındaki bir değişiklikle değil, daha ziyade özellikle sıcaklıklardaki artışla ilişkilendirilmiştir. Başka bir deyişle, yağışların kardan ziyade yağmur formunda gerçekleşmesi ile yüzey akımlarının nehir yatağına ulaşması daha kolaylaşarak yatak akımları eskisinden daha erken bir dönemde gerçekleşmektedir (Arnell, 1999). Yucel, Guventurk, and Sen (2015) Türkiye'nin Doğu Anadolu bölgesinde halihazırdaki kar akımlarından kaynaklanan akarsu akış zamanlamasının 1970-2010 dönemi iklim ortalamasına kıyasla bir hafta önce gerçekleştiğini göstermişlerdir. Bölgesel iklim simülasyonlarını yüksek emisyon senaryosu altında yürüterek, yüzyılın sonunda bu değişimin bir ay kadar büyük olacağını öngörmüşlerdir. Yüzyıl sonu tahminleri, Fırat-Dicle ve Aras havzaları için yüzeysel akışta önemli bir düşüş gösterirken, Çoruh havzası için daha az bir düşüş tespit edilmiştir. Yilmaz and Imteaz (2011) Yukarı Fırat Havzası akımlarının 2070-2100 periyodu için iklim değişkenleri altında olası davranışını LRBM ve HEC-HMS modellerini kullanarak modellemişlerdir. Her iki modelde de kar erimeleri modellenirken sıcaklık indeksi metodu kullanılmıştır. Meteorolojik iklim değişkenleri global ölçekteki ECHAM5 verilerinin RegCM3 modeli ile indirgenmesi ile elde edilmiştir. Hidrolojik model sonuçlarına göre belirtilen periyotta yaz ve bahar dönemi akımlarında önemli miktarda düşüş beklenmektedir. Özellikle ilkbaharda azalan kar örtüsü derinliği, ilkbahar kar erimesi akışının zamanlaması ve büyüklüğ̈̈nün bölgesel hidrolojik sistemlere etkisinden dolayı kritik öneme sahiptir. Türkiye'nin doğu bölgeleri, dağlık arazi ve kuru iklim ile karakterizedir. Özellikle doğudaki bu dağlık kesimlerde ilkbahar ve yaz ayları başlarında kar erimesi nedeniyle oluşan akarsu akışı, yıllık toplam akış hacminin yaklaşık\% 60-70'ini oluşturması bakımından önemlidir (Şorman, 2004). Bu sebeple, büyük rezervuarların bulunduğu Fırat ve Dicle havzalarındaki kar erimesine bağlı akışın zamanlaması ve miktarının tahmin edilmesi, su kaynaklarının etkin yönetimi için çok önemlidir (Sen, Unal, Bozkurt, \& Kindap, 2011).

Bu çalışmada HSPF Modelinin Türkiye'de Doğu Anadolu Bölgesi'ndeki kar erimesinin etkili olduğu dağlık havzalara uygulanabilirliği amaçlanarak öncelikli olarak kar erimesine ve akışa etki eden HSPF model parametreleri elde edilmiştir. Böylelikle ilgili modeli kullanılarak 2010-2011 kış periyodu boyunca bir yıllık kar birikme ve erime sezonunu içerecek şekilde üç farklı lokasyonda gerçekleşen fiziksel davranış kurulan model yardımı ile benzeştirilmiştir. Kurulan modelde iklim değişikliği etkilerinin yağış ve sıcaklık üzerindeki beklenen trendlerinin değerlendirilmesi ile 2050 yılı için beklenen olası kar kütlesi davranışı ile kütleden salınan ve yüzeysel akışa geçen su miktarlarının davranışı incelenmiştir.

\section{Materyal ve Metot}

\subsection{BASINS'in Özellikleri}

BASINS 4.0 güncel sürümü, açık kaynak kodlu MapWindow CBS platformu üzerinde yapılandırılmıştır. BASINS, WinHSPF, WDMUtil ve GenSen yardımcı araçlarını da içermektedir.

-WinHSPF, HSPF modelinin Windows XPTM işletim sistemi altında çalışan grafiksel kullanıcı arayüzlü sürümüdür.

- WDMUtil, alansal havza verileri ile meteorolojik ve diğer zaman serisi verilerini içeren HSPF model girdilerini oluşturup yönetilmesini sağlamaktadır.

- GenScn, HSPF model çıktıları ile çalışan bir son işlemci ve senaryo analizi aracıdır. (Anonymous, 2007).

BASINS içinde çalışan bir veri indirme aracı ile Amerik Birleşik Devletleri'ndeki (ABD) havzalar ile ilgili sürekli güncelleştirilen veriler, BASINS web sitesinden yüklenebilmektedir. Bu veritabanları kullanılarak, havza analizi ve modellemesi işlemleri 
kolaylaştırılabilmektedir. Bu veritabanları, standart bir paylaşım ve yayınlanma protokolü (örneğin veri yapıları ve dosya biçimleri) ile organize edilmiştir. ABD toprakları dört seviyede belirlenen oldukça küçük hidrolojik birimlere ayrılmıştır. Bunlar; ortamın hidrolojik özelliklerine bağlı olarak bölgeler, alt bölgeler, hesaplama birimleri ve kataloglama birimleri olarak sınıflandırılmıştır. Hidrolojik birimler kendi aralarında küçükten (kataloglama birimleri) büyüğe (bölgeler) doğru organize edilmiştir. Diğer bir deyişle, HUC bir havzanın en küçük birimidir. ABD topraklarının tümü 2264 hidrolojik birime bölünmüştür (Seaber, Kapinos, \& Knapp, 1987).

BASINS'in ABD'deki havza analizi ve su kalite modellemesine yönelik birçok uygulamaya literatürde yer verilmiştir (Bergman, Green, \& Donnangelo, 2002; Carrubba, 2000; Choi \& Deal, 2008; El-Kaddah \& Carey, 2004; Endreny, Somerlot, \& Hassett, 2003; Im, Brannan, Mostaghimi, \& Cho, 2004; Shirinian-Orlando \& Uchrin, 2007). BASINS içindeki modelleme araçları tek başlarına çalışabilir olsalar da (Tzoraki \& Nikolaidis, 2007) yazılım tasarım ayrıntıları ve veri yükleme araçlarının özellikleri nedeniyle, ABD dışındaki havzalarda pek uygulama alanı bulamamışlardır. BASINS'in CBS becerilerinden, havzanın karakterize edilmesinde ve modellerin çalıştırılması için gerekli girdi verilerinin hazırlanmasında yararlanılabilmektedir. Hidrolojik simülasyonların gerçekleştirileceği HSPF modelinin çalıştırılabilmesi için havzaya ait hidro-jeolojik veri tabanının BASINS ortamında ABD tarafindan kullanılan standartlara göre modifiye edilmesi gerekmektedir.

\subsection{HSPF Model Parametreleri}

Poligonal bir arazi parçası, simüle edilmiş havzanın alt bölümlerinden biridir. Sınırlar kullanıcının ihtiyaçlarına göre kurulur. Genellikle her bir parça (segment) benzer hidrolojik karakteristikli bir alan olarak tanımlanır. Modelleme amaçları için su, sediment ve su kalitesi öğeleri havzadan yanlamasına doğru aşağı eğimli bir parça (segment, poligonal alan) veya bir rezervuara bırakılır. Su bütçesine etki edecek kadar yeterince infiltrasyona izin veren kapasiteye sahip bir arazi parçası geçirimli olarak düşünülür.

HSPF kavramsal bir model olup karmaşık yapıdadır. HSPF modeli ile gerçekleştirilecek olan yağış-akış simülasyonları geçirimli ve geçirimsiz zeminlerde ayrı ayrı olmak üzere en temelde ATEMP, SNOW, PWATER ve RCHRES modülleri sirasıyla işletilerek gerçekleştirilir. Farklı yükseltilerde bulunan kar kütlesinden salınan veya yağı̧̧ kaynakı herhangi bir suyun belli bir arazi parçasındaki sızma, ara akış veya çıkış akımlarını tespit etmek, su bütçesi hesaplamalarını gerçekleştirebilmek için PWATER modülü aktive edilir. Yüzeysel akım değerlerinin belli bir gözlem noktadasındaki değerlerinin tespiti için ise nihai olarak açık kanal akımı ile ilgili hidrolik hesaplamaların yapıldığı RCHRES modülü sonuçları kullanılır. PWATER ve RCHRES modülleri de oldukça kapsamlı ve kompleks yapıda olduğu için aşağıda sadece bu çalışmaya esas olan kar kütlesinden salınan serbest su miktarının ve zamanının belirlenebilmesi için kullanılan ve bunun için karın kütlesel davranışının hesaplandığı ATEMP ve SNOW modüllerinin fiziksel ve ampirik ilişkilerinden bahsedilmektedir.

\subsubsection{Hava Sıcaklı̆̆ı Yükseklik Farkı-ATEMP}

ATEMP'in amacı havzadaki herhangi bir arazi parçası üzerindeki ortalama hava sıcaklığını gösteren girdi hava sıcaklığını modifiye etmektir (değiştirmektir). Hava sıcaklı̆̆ doğrulaması, arazi parçasının yüksekliği sıcaklık istasyonunun (ölçme aletinin) yüksekliğinden önemli derecede farklı ise gereklidir. Eğer yükseklik için doğrulamaya gerek yoksa bu modül kullanılmayabilir.

Hava sıcaklığı için düşme oranı zaman aralığı süresinde yağışa bağlıdır. Eğer yağış meydana gelirse, yükseklikteki fark foot başına 0,0035 derece Fahrenhayt' 1 lk $\left(0,638^{\circ} \mathrm{C} / 100 \mathrm{~m}\right)$ bir sslak düşme oranı (wet lapse rate) kabul edilir. Aksi takdirde günde zamanla değişen bir kuru düşme oranı kullanılır. $0,0035^{\circ} \mathrm{F} /$ foot $\left(0,638^{\circ} \mathrm{C} / 100 \mathrm{~m}\right)$ ile $0,005^{\circ} \mathrm{F} / \mathrm{ft}\left(0,911^{\circ} \mathrm{C} / 100 \mathrm{~m}\right)$ arasında değişen 24 saatlik bir tablonun kuru düşme oranları sisteme yerleştirilmiştir. Doğrulanmış hava sıcaklığı:

$$
\begin{aligned}
& \text { AIRTMP }=\text { GATMP }- \text { LAPS } * \text { ELDAT } \\
& \text { AIRTMP }=\text { Doğrulanmış hava sıcaklığı (derece F) } \\
& \text { GATMP }=\text { İstasyonda hava sıcaklığı }(\text { derece F })
\end{aligned}
$$

LAPS $=$ Düşme oranı $($ derece $F /$ foot $)$

ELDAT = Arazi parçası ve istasyon arasındaki yükseklik farkı $(\mathrm{ft})$

\subsubsection{Kar ve Buzun Birikmesi ve Erimesi - SNOW}

SNOW karın düşme, birikme ve erimesinden elde edilen akışla ilgili bir modüldür. Bu özellikle kar yağışının etkili olduğu havzalarda kar erimesinden elde edilen akışın çıkış debisinin çoğuna neden olduğundan dolayı hidrolojik paketin gerekli bir bölümüdür.

Bir arazi parçası üzerinde kar birikmesi ve erimesi ile alakalı işlemleri modellemek için iki seçenek mevcuttur. İlk yöntem, İstihkâm Sınıfi (Corps of Engineers) (Anonymous, 1956), Anderson and Crawford (1964) ve Anderson (1968) tarafindan yapılan çalışmalara dayanan bir enerji dengesi yaklaşımıdır. Fiziksel ilişkiler iyi bilinmediğginde ampirik ilişkiler kullanılır. Kar algoritmaları, yağış̧ın yağmur veya kar olup olmadığını belirlemek için, kar kütlesi için bir enerji dengesi simüle etmek ve kar kütlesine 1sı akışının etkisini belirlemek için meteorolojik verileri kullanır. Şekil 2.1'de kar birikme ve erime işlemlerindeki süreçler gösterilmektedir.

İsteğe bağlı, ikinci bir kar erime yöntemi ise sıcaklık indeksini veya derece-gün yaklaşımını (Rango \& Martinec, 1995) kullanır. Orijinal yöntemdeki çoğu işlemler, atmosferik 1sı değişiminden dolayı kar erimesi hava sıcaklı̆ğ ve ampirik bir derece-gün faktörü kullanılarak hesaplanarak devam ettirilir. Bu yaklaşım meteorolojik veriler için yağış ve hava sıcaklığına gereksinimleri azaltır.

Altı meteorolojik zaman serisi, seçilen seçeneğe bağlı olarak simüle edilen her arazi parçası için SNOW tarafından gerekli olabilir (Tablo 2.1). Bu çalışmada enerji dengesi (bütçesi) metodolojisi kullanılacaktır. 


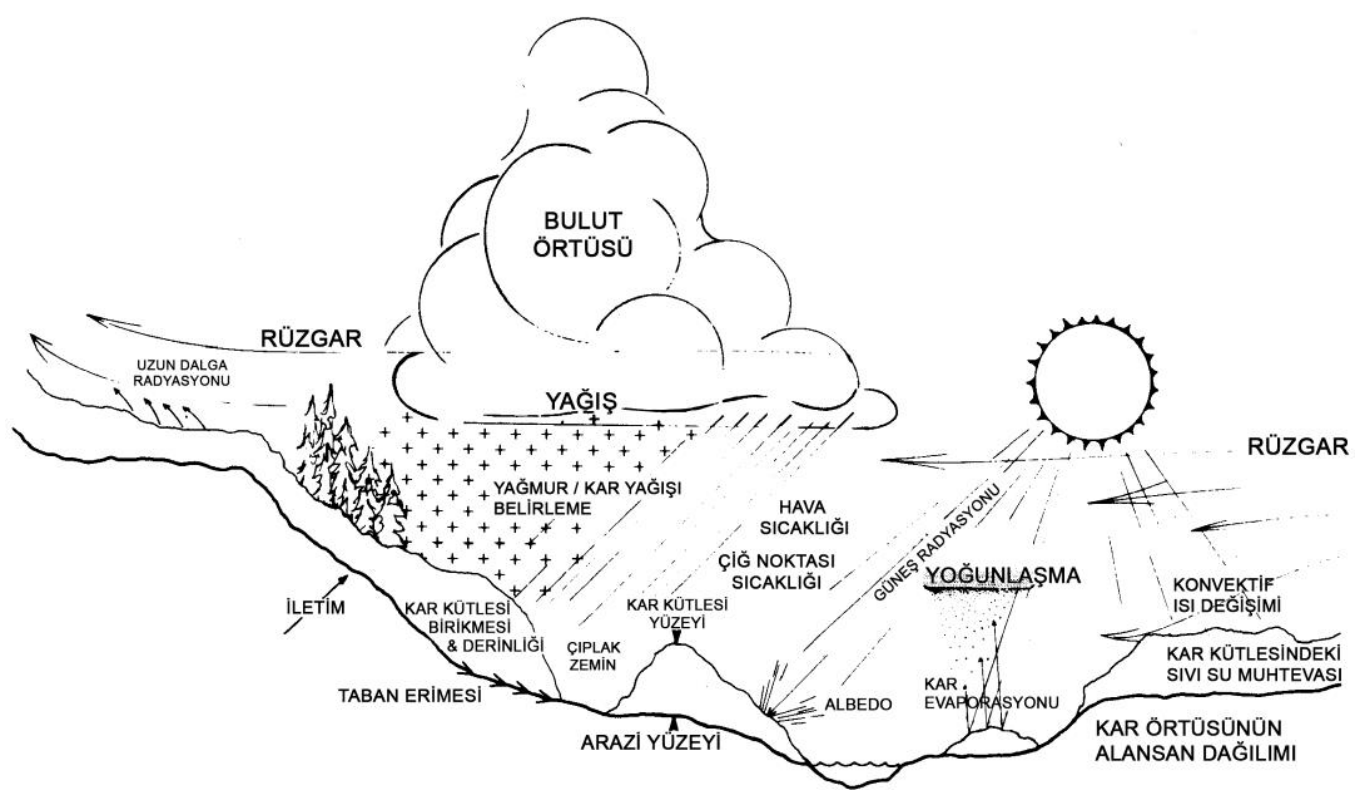

Şekil 2.1. Kar birikme ve erime işlem süreci

$\mathrm{Bu}$ zaman serilerinin hepsinden bir değer, her simülasyon aralı̆ı̆ını başlangıcında SNOW'a girdidir. Buna rağmen, meteorolojik zaman serilerinin bazıları kar kütlesinden evaporasyonun potansiyel oranının hesabı gibi sadece ara hesaplama oranları için kullanılır.

Hava sıcaklığı, yağışın yağmur veya kar şeklinde olup olmadığını belirlemek için kullanılır. TSNOW kritik sıcaklığı çiğ noktasına dayanılarak doygun olmayan şartlarda bir derece $\mathrm{F}^{\prime} \mathrm{a}\left(1,8^{\circ} \mathrm{C}\right)$ kadar yukarı doğru ayarlanabilir. Bu ayarlama sıcaklık indeks yöntemi kullanılırken opsiyoneldir ve sadece geçirimli arazi parçasına (Pervious Land Segment, PLS) çiğ noktası zaman serileri girdi olarak sağlandığında kullanılır.

Tablo 2.1. SNOW modülünde kullanilan meteorolojik zaman serileri

\begin{tabular}{ccc}
\hline Meteorolojik Nicelik & Enerji Dengesi & Sıcaklık İndeksi \\
\hline Yağış & Gerekli & Gerekli \\
Hava Sıcaklığı & Gerekli & Gerekli \\
Güneş Radyasyonu & Gerekli & Kullanılmıyor \\
Çiğ Noktası & Gerekli & Opsiyonel \\
Rüzgâr Hızı & Gerekli & Kullanılmıyor \\
Bulut Örtüsü & Opsiyonel & Kullanılmıyor \\
\hline
\end{tabular}

Kar bir defa zemin üzerinde birikmeye başlarsa, kar birikmesi ve erimesi hesapları gerçekleşir. Kar kütlesinin erimesini etkileyen ısının beş kaynă̆ı simüle edilebilir (sıcaklık indeks yaklaşımı kullanıldı̆̆ında, ilk üç kaynak derece-gün faktörü altında dâhil edilmiştir).

1. Net radyasyon 1Sis1 (RADHT), uzun dalga ve kisa dalga

2. Havadan hissedilir isının konveksiyonu (CONVHT)

3. Kar kütlesi üzerinde nemli havanın yoğunlaşmasıyla gizli ısı transferi (CONDHT)

4. Yağmurdan 1S1, yağmur yağışından hissedilir 1Sı (RNSHT) ve kar kütlesi üzerinde yağmurun donmasından gizli 1S1

5. Zemin üzerinden kar kütlesine 1sı iletimi (GMELTR)

Evaporasyondan gizli 1sı gibi diğer 1sı değişimi işlemleri daha az önemli olduğu düşünülür ve simüle edilmez. Eğer enerji dengesi seçeneği açıksa, RADHT, CONVHT ve CONDHT için enerji hesaplamaları HEXCHR alt programı tarafindan çalıştırılır. Bu üç 1Sı kaynağının toplamı MOSTHT ile ifade edilir. Eğer derece-gün seçeneği açıksa, MOSTHT, hava sıcaklığı ve derece gün faktörü kullanılarak DEGDAY alt programında doğrudan hesaplanır. Yağmur donmasından gizli 1sı WARMUP alt programında dikkate alınır. RNSHT, SNOW ana alt programında hesaplanır. GMELTR, GMELT alt programında hesaplanır ve kar kütlesinden ayrıca çıkarılır.

İşlemlerde benzerliğin sağlanabilmesi için bütün hesaplamalarda enerji değerleri, eritecekleri su eşdeğeri cinsinden hesaplanır. 32 derece $\mathrm{F}\left(0^{\circ} \mathrm{C}\right)$ 'da 1 inç $(2,54 \mathrm{~cm})$ su eşdeğerindeki karın erimesi için yüzeyde $\mathrm{cm}^{2}$ başına 202,4 kalori gerekir. RNSHT'yi de içeren ve kar kütlesine giren bütün 1sı kaynaklarının pozitif veya sıfır olduğu kabul edilirken RADHT negatif değer alabilir (ısının kütleyi terketmesi). 
Atmosferden gelen net 1Sı (MOSTHT ve RNSHT’nin toplamı) kar kütlesini 1sıtmak için kullanılır. Kar kütlesi, yağmur donması ile serbest bırakılan gizli 1sı tarafından ilaveten ısıtılmış olabilir. Kar kütlesini 1sıtmak için gerekli olan 32 derece $\mathrm{F}\left(0^{\circ} \mathrm{C}\right)$ üzerinde herhangi fazla ısı kütleyi eritmek için kullanılır. Aynı şekilde negatif bir 1sı deposu üreten net 1sı kaybı, kar kütlesini soğutmak için kullanılır. Ayrıca, zeminden gelen 1sı kar kütlesini atmosferik 1sı kaynaklarından bağımsız olarak alt taraftan eritmektedir. Bunun haricinde erime oranı kar kütlesinin sıcaklığına bağlıdır.

Şekil 2.2'de SNOW bölümünde modellenen nemin işlemleriyle ilgili şematik bir gösterim verilmiştir. Yağış, kar kütlesi veya zemin üzerine yağmur veya kar şeklinde düşebilir. Simüle edildiğinde evaporasyon sadece kütlenin donmuş kısmından olur (PACKF). Kütlenin donmuş kısmı kar ve buzdan oluşur. PACKF'in buz kısmının kar kütlesinin alt kısımlarında olduğu düşünülür, bu yüzden zeminden ısı iletildiğinde ilk eriyecek kısımdır. Benzer şekilde, PACKF'in kar kısmı atmosferik 1sı arttığında eriyecek ilk kısımdır. PACKF'in eriyen kısmı ve/veya kar kütlesine düşen yağmur ile kar kütlesinin taşıma kapasitesini aşabilecek, toplam kar kütlesinin sıvı su kısmı üretilir. Üzerinde kar kütlesi olmayan çıplak arazideki su akışı ve yağmur ayrıca PWATER veya IWATER (tamamiyle geçirimsiz arazi parçalarının simüle edildiği modül) bölümüne girdi olarak konulur.

Yağmurdan (RNSHT) kar kütlesine giren ısı transferi SNOW ana alt programında aşağıdaki fiziksel tabanlı denklem ile hesaplanır:

$$
\begin{aligned}
& \text { RNSHT = (AIRTMP - 32,0)*RAINF/144,0 } \\
& \text { AIRTMP = Havanın sıcaklığı (derece F) } \\
& \text { RAINF = Yağmur yüksekliği (inç) } \\
& 144,0=\text { Erimenin eşdeğer yüksekliğine dönüştürmek için faktör } \\
& 32,0=\text { Donma noktası (derece F) }
\end{aligned}
$$

Kar kütlesinin diğer karakteristikleri de SNOW ana alt programında belirlenir. Mevcut kar kütlesi tarafından arazinin ne kadarının karla kaplı olduğu kar kütlesinin derinliğinin COVIND parametresinin bir fonksiyonu olan bir örtü indeksine (COVINX) bölünmesiyle ve EFFPRC alt programında açıklanan kütlenin tarihsel verileriyle tahmin edilir. Kar kütlesinin sıcaklığı:

$$
\begin{aligned}
& \text { PAKTMP }=32,0-\text { NEGHTS/(0,00695*PACKF) } \\
& \text { PAKTMP }=\text { Kar kütlesinin ortalama sıcaklığ }(\text { (derece F) } \\
& \text { NEGHTS }=\text { Negatif ısı deposu (inç olarak su eşdeğeri) } \\
& \text { PACKF = Kar kütlesinin donmuş içeriği (inç olarak su eşdeğeri) } \\
& 0,00695=\text { Fiziksel tabanlı dönüştürme faktörü }
\end{aligned}
$$

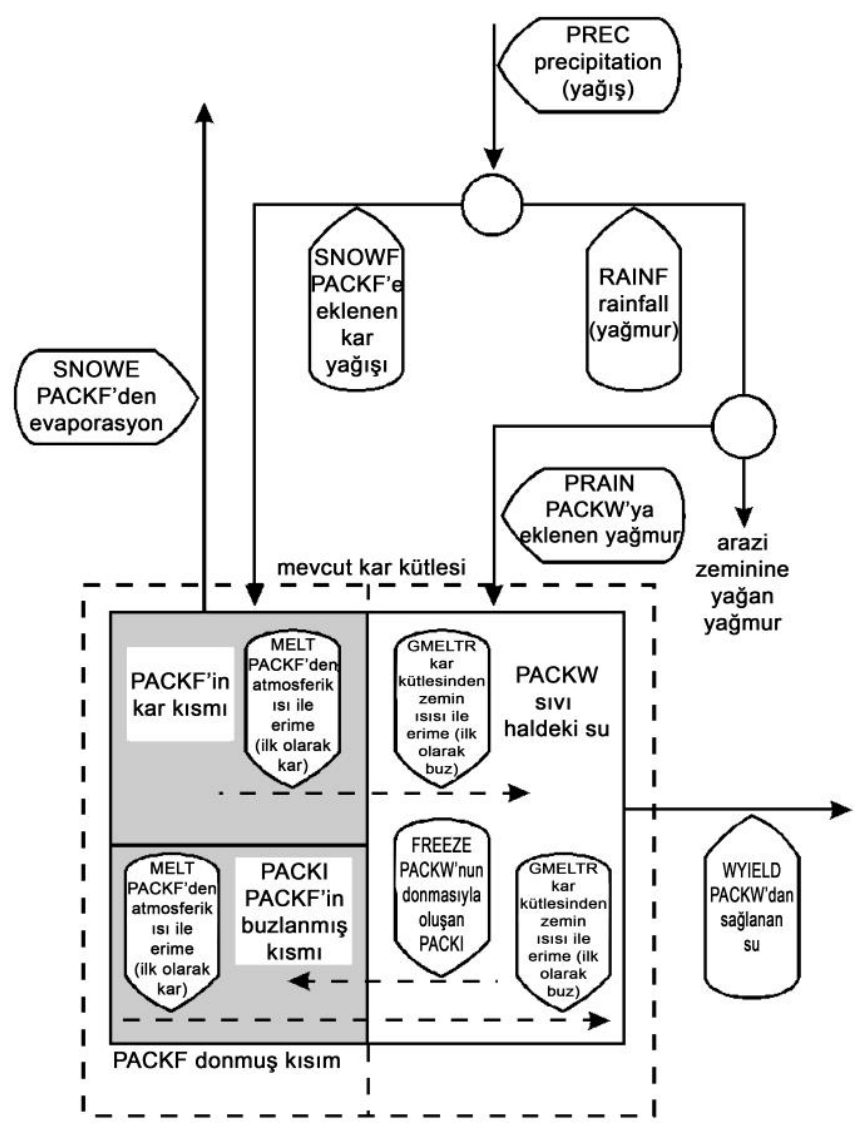

Şekil 2.2. SNOW bölümünde modellenen nem şeması 


\subsection{2.a. Meteorolojik Şartlar - METEOR}

METEOR alt programı ampirik denklemleri kullanarak karla ilgili spesifik (özel) ișlemler üzerinde belirli meteorolojik şartların etkilerini tahmin eder. Yağışın kar mı yoksa yağmur mu şeklinde olduğunu belirler. Yağışıı şekli, akışın ve kar erimesinin güvenilir bir şekilde simüle edilmesi için kritiktir. Kar yağdığı zaman, yoğunluk yeni kar kütlesinin yüksekliğini (derinliğini) belirlemek için hesaplanır. Açık olan gökyüzü parçası da radyasyon algoritmalarında kullanılmak üzere (eğer gerekliyse) tahmin edilir ve eğer hava sıcaklığından daha sıcaksa istasyonun çiğ noktası sıcaklı̆̆ı doğrulanır.

Eğer çiğ noktası girdi ise, doğrulanır ve kar yă̆ışı için kritik sıcaklık ayarlaması için kullanılır. Bir istasyonun çiğ noktasının hava sıcaklığından yüksek olması fiziksel olarak mümkün değildir ve kar kütlesi evaporasyonunun hesaplanmasında hatalı sonuçlar verir. Bu yüzden, bu durum oluştuğunda çiğ noktası hava sıcaklığına eşit alınır. Aksi takdirde istasyon çiğ noktası kullanılır. Aşağıdaki ifade kar yağışının oluştuğu etkili hava sıcaklığı düşüşünün saatlik olarak hesaplanmasında kullanılır:

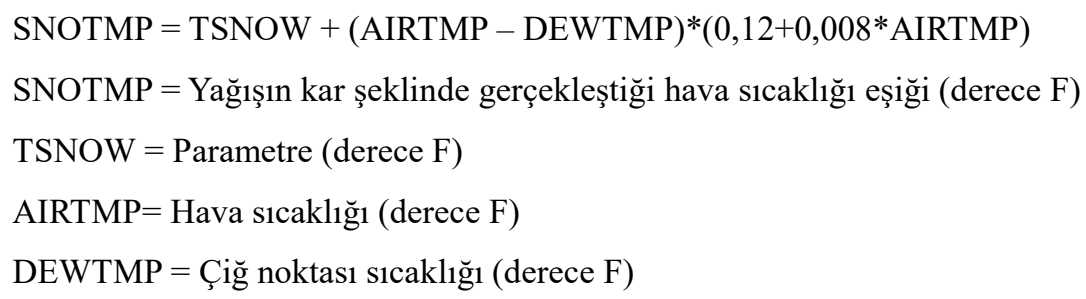

Denklem 2.4 ile hesaplanan SNOTMP'nin TSNOW'dan maksimum bir derece F sapmasına izin verilir. Eğer çiğ noktası girdi değil ise o zaman SNOTMP daima TSNOW'a eşit olur. AIRTMP, SNOTMP'ye eşit veya büyük olduğunda yağışın yağmur şeklinde olduğu farz edilir. Kar yağışı meydana geldiğinde, yoğunluğu hava sıcaklığının bir fonksiyonu olarak aşağıdaki gibi tahmin edilir:

RDNSN $=$ RDCSN $+($ AIRTMP $/ 100,0) * * 2$

RDNSN $=$ Yeni kar yağı̧ıının yoğunluğu $\left(0^{\circ} \mathrm{F}=-17,8^{\circ} \mathrm{C}\right.$ veya daha fazla sıcaklıklarda), sıvı su ile ilgili

RDCSN = Hava sıcaklı̆̆ının sıfır derece F ve altında olduğu zaman yağan yeni karın yoğunluğunun suyun yoğunluğuna oranını belirten parametre

RDNSN, kar eklenmesinden dolayı kar kütlesinin yeni derinliğini hesaplamak için EFFPRC'nin alt programında kullanılır. Bu ve diğer bütün kar yoğunluğu terimleri birim kar kütlesinin derinliği başına (inç) birim su eşdeğeridir (inç).

Enerji dengesi seçeneği seçildiğinde açık olan gökyüzü parçası oranına (SKYCLR) bulutlardan kar kütlesine doğru etki eden uzun dalga geri radyasyonunun hesaplanması için ihtiyaç duyulur (HEXCHR alt programında hesaplanır). Eğer bulut örtüsü bir zaman serisi olarak girdi ise, SKYCLR doğrudan ondan hesaplanır. Aksi halde, SKYCLR son yağış olayının olduğu zamandan itibaren tahmin edilir. Yağışın meydana gelmesi sırasında bir aralıkta, SKYCLR 0,15 minimum değerine ayarlanır. Olaylar arasında, her simülasyon zaman aralığında aşă̆ıdaki şekilde artar:

SKYCLR $=$ SKYCLR $+(0,0004 *$ DELT $)$

DELT $=$ Simülasyon zaman aralığı (dakika) gösterir.

SKYCLR, resetlemeye neden olan ya birliğe (unity) veya yağışa ulaşıncaya kadar artar.

\subsection{2.b. Kütle Üzerine Yăğıs - EFFPRC}

$\mathrm{Bu}$ alt programın amacı düşen karı kütleye eklemek, kar kütlesi üzerine düşen yağmurun miktarını belirlemek ve yeni kar miktarını dikkate almak için kar kütlesinin "dullness" değerini ayarlamaktır.

Kar veya yağmur şeklinde düşen yağışın miktarı METEOR alt programında belirlenir. EFFPRC alt programı kar yağışı veya yağmurun arazi parçası üzerine olan etkisini açıklar. Bu alt program, kütle üzerine yağan kar miktarının kar yoğunluğuna bölünmesiyle analiz edilen, kar kütlesinin derinliğinin artması ile başlar.

Kar kütlesiyle örtülü arazi parçasının bölümü (SNOCOV), alansal kapsama indeksinin (COVINX) yeniden hesaplanmasıyla belirlenir. Kar kütlesinin donmuş miktarı (PACKF), kar örtüsü tarafından alanın tamamen kaplanmasını sağlamak için gereken PACKF yüksekliğini açıklayan parametre eşiğini (COVIND) aştığı zaman, COVINX değeri COVIND'e eşit olarak ayarlanır. Aksi halde, COVINX, PACKF'in en büyük önceki değerine eşitlenir. Eğer PACKF $<$ COVINX ise SNOCOV=PACKF/COVINX olur. Kar kütlesi üzerine yağan yağmurun miktarı, yağmur olarak düşen yağış parçasının SNOCOV ile çarpılması sonucunda elde edilir. Kar kütlesi üzerine düşen yağmur ya kütlenin donmuş kısmına eklenip, aynı zamanda kütleyi ısıtmak için kullanılan 1sıyı üreterek (WARMUP alt programında) donar yada kütlenin sıvı su muhtevasını artırır (LIQUID alt programında). Kar kütlesinin üzerine düşmeyen yağmurun ise çıplak arazi üzerine düştüğü farz edilir.

Enerji dengesi seçeneği altında, kar kütlesi yüzeyinin albedosu, RADHT radyasyon 1sı akışııı hesaplamak için kullanılır. Kar yağışı olduğunda, kar kütlesinin “dullness” indeksi (DULL) bu zaman aralığı için kar yağı̧ıııın bin katı kadar azaltılır. Buna rağmen, eğer kar yağışının bin katı, DULL un önceki değerinden büyükse, DULL mükemmel yansıtıcılığı olan karın yeni bir katmanı için hesaplama yapmak için sıfıra ayarlanır. Aksi halde, kar yağışı olmadığında, DULL maksimum 800'e kadar saat başına bir indeks birimi artar. Bu yüzden DULL fiziksel birimi olmayan, bir indeks olarak kullanılan ampirik bir terimdir. DULL, HEXCHR alt programında kısa dalga enerji hesaplamalarında sırasında kullanılan kar kütlesinin albedosunu belirlemek için kullanılır. 


\subsection{2.c. Kütle Sıkışması (Compact) - COMPAC}

Yeni karın eklenmesi, EFFPRC alt programındaki gibi kar kütlesinin derinliğini artırmasının yanı sıra yoğunluğunu da azaltacaktır. Kütle, maksimum bir yoğunluğa ulaşıncaya kadar zamanla sıkışma eğiliminde olacaktır. COMPAC alt programının amacı sıkışma oranını belirlemek ve sıkışmadan dolayı derinlikteki gerçek değişimi hesaplamaktır.

Kar için bağıl yoğunluk \%55’ten düşük olduğunda sıkışmanın gerçekleştiği farz edilir. Sıkışmanın oranı aşağıdaki ampirik ifadeye göre hesaplanır:

COMPCT $=1,0-(0,00002 *$ DELT60*PDEPTH $*(0,55-$ RDENPF $))$

COMPCT $=$ Aralık başına kar kütlesi sıkışmasının birim oranı

DELT60 $=$ Bir aralıktaki saatlerin sayıs 1

PDEPTH = Toplam kar kütlesinin inç olarak kar kütlesi derinliği

RDENPF = Sıvı suya göre kütlenin yoğunluğu

PDEPTH için yeni değer COMPCT ile PDEPTH çarpımıdır. PDEPTH, LIQUID alt programında belirlendiği gibi sıvı su tutma kapasitesini etkileyen kar kütlesinin bağıl yoğunluğunu hesaplamak için kullanılır.

\subsection{2.d. Kütleden Buharlaşma - SNOWEV}

SNOWEV alt programı enerji dengesi yöntemi kullanılmaya başlandığında kar kütlesinden buharlaşmayı (süblimleşme) tahmin eder.

Kar kütlesinden buharlaşma sadece havanın buhar basıncı kar yüzeyindeki buhar basıncından daha az olduğunda gerçekleşir ki bu durum ancak hava buhar basıncının 6,108 mbar'dan daha az olduğu zaman meydana gelmektedir. Nitekim, bu değer kar kütlesi üstündeki ince yüzey filmi halindeki havanın ulaşabildiği maksimum buhar basıncıdır. Bu şart karşılandığı zaman evaporasyon aşağıdaki ampirik ilişki ile hesaplanır:

SNOWEP $=$ SNOEVP $* 0,0002 *$ WINMOV $*($ SATVAP-VAP $) *$ SNOCOV

SNOWEP = Kar kütlesinin donmuş kısmından buharlaşmanın potansiyel oranı (su eşdeğeri/aralık, inç olarak)

SNOEVP $=$ Arazi şartlarına göre hesaplamayı ayarlamak için kullanılan parametre

WINMOV = Rüzgâr akımı, hareketi (mil/zaman aralığı)

SATVAP = Mevcut hava sıcaklığında havanın doygun buhar basıncı (mbar)

$\mathrm{VAP}=$ Mevcut hava sıcaklı̆̆ında havanın buhar basıncı (mbar)

SNOCOV = Kar kütlesi tarafindan kaplanan arazi parçasının bölümü (fraction)

Eğer yeterli kar kütlesi varsa potansiyel evaporasyon (SNOWEP) gerçekleşecektir. Aksi takdirde, sadece kalan kütle buharlaşacaktır. Diğer durum için, buharlaşma sadece kar kütlesinin donmuş miktarından meydana gelecektir. Buharlaşmanın kütlenin içindeki 1sı dengesine etkisinin önemsiz olduğu düşünülür.

\subsection{2.e. Isı Değişim Oranları Tahmini - HEXCHR}

$\mathrm{Bu}$ alt programın amacı, enerji dengesi yöntemi kullanıldığında yoğunlaşma, iletim ve radyasyondan dolayı atmosferden isı değişimini tahmin etmektir.

Yoğunlaşma ile elde edilmiş ısının belirlenmesi yöntemi: Nemli hava kütleleri kar kütlesi üzerinde gezindiğinde, yoğunlaşma gizli ısısının transferi önemli olabilir. Hava, kar kütlesi üzerinde yoğunlaşacak kadar nemli olduğunda yoğunlaşma meydana gelir. Yani, havanın buhar basıncı 6,108 mbar'dan büyük olduğu zaman yoğunlaşma gözlenir. Bu fiziksel işlem kar buharlaşmasının tersidir. Bu durumda 1s1, başka bir ampirik ilişki ile hesaplanarak üretilir:

CONDHT $=8,59 *($ VAP- 6,108$) *$ CCFACT $* 0,00026 *$ WINMOV

CONDHT = Kar kütlesine yoğunlaşma 1sı akışı (su eşdeğeri/zaman aralığı, inç olarak)

VAP = Mevcut hava sıcaklığında havanın buhar basıncı (mbar)

CCFACT $=$ Saha (alan, arazi) şartlarına göre erime değerlerini doğrulamak için kullanılan parametre

WINMOV = Rüzgâr akımı, hareketi (mil/zaman aralığı)

CONDHT sadece pozitif veya sıfir olabilir (yani kütleye giren)

İletim ile elde edilmiş ısının belirlenmesi yöntemi: Atmosferdeki türbülans değişimi ile elde edilen 1sı sadece, hava sıcaklıkları donma noktasından büyük olduğu zaman meydana gelebilir. Isının bu iletimi ampirik ifade ile hesaplanır:

CONVHT $=($ AIRTMP-32,0)*(1,0-0,3*MELEV $/ 10000,0) *$ CCFACT $* 0,00026 *$ WINMOV

CONVHT = Kar kütlesine iletim 1sı akışı (su eşdeğeri/zaman aralığı, inç olarak) 
AIRTMP $=$ Hava sicaklığ $\left({ }^{\circ} \mathrm{F}\right)$

MELEV = Deniz seviyesinden arazi parçasının ortalama yüksekliği (ft)

Bu simülasyonda, CONVHT sadece pozitif veya sıfir olabilir; yani, giren enerjidir.

Radyasyon ile elde edilmiş ısının belirlenmesi yöntemi: Radyasyon ile elde edilmiş ısı:

RADHT $=($ SHORT + LONG $) / 203,2$

RADHT = Kar kütlesine radyasyon 1sı akışı (su eşdeğeri/ zaman aralığı, inç olarak)

SHORT $=$ Net güneş veya kısa dalga radyasyon (langley/ zaman aralığı $)(1$ Langley $=1$ gram kalori/cm2 $)$

LONG = Net karasal veya uzun dalga radyasyon (langley/ zaman aralığı)

203,2 sabiti 32 derece F'da kardan erimede, 1 inç yüksekliğinde su üretmek için gerekli olan langley miktarıdır.

RADHT pozitif veya negatif olabilir; yani, giren veya çıkan enerji olabilir.

SHORT ve LONG aşağıdaki gibi hesaplanır. Bir zaman serisine gerek duyulan güneş radyasyonu, albedo ve gölge etkisiyle değiştirilir. Kar kütlesinin albedosu veya yansitıcılığı kütlenin dullness değeri (DULL) ve sezonun bir fonksiyonudur. 6 yaz ayı için albedo değerleri (ALBEDO) aşağıdaki denklemle hesaplanır:

ALBEDO $=0,80-0,10 *($ DULL $/ 24,0) * * 0,5$

Kış aylarında ise albedo değerleri şu denklemle hesaplanır:

ALBEDO $=0,85-0,07 *(\text { DULL } / 24,0)^{* *} 0,5$

ALBEDO, yaz ayları için 0,45, kış ayları için ise 0,60 minimum değerine izin verir. Arazi parçasının dünya üzerindeki yarım küresel konumu yaz ve kış periyotlarının belirlemesi için yukarıdaki denklemler kullanıldığında dikkate alınır. Kuzey yarım küre için veri girişi pozitif olan enlem parametresi kullanılarak yapilır.

Kütlenin albedosu bir defa bulunduğunda güneş radyasyonu (SHORT) aşağıdaki denkleme göre modifiye edilir (değiştirilir):

SHORT $=$ SOLRAD $*(1,0-$ ALBEDO $) *(1,0-$ SHADE $)$

SOLRAD = Güneş radyasyonu (langley/aralık)

SHADE $=$ Gölgelenmiş arazi parçası oranını belirten parametre

Daha yaygın bir şekilde ölçülen kısa dalga radyasyonunun aksine, uzun dalga radyasyonu (LONG) kar kütlesinin ve çevresinin yayma özelliklerinin teorik değerlendirmesinden tahmin edilir. Aşağıdaki denklemler, Stefan'ın Siyah Cisim Yasası'na dayanan eğrilerin (Şekil 2.3) lineer yaklaşımlarıdır ve sadece hava sıcaklığına bağlı sabitlerle değişir.

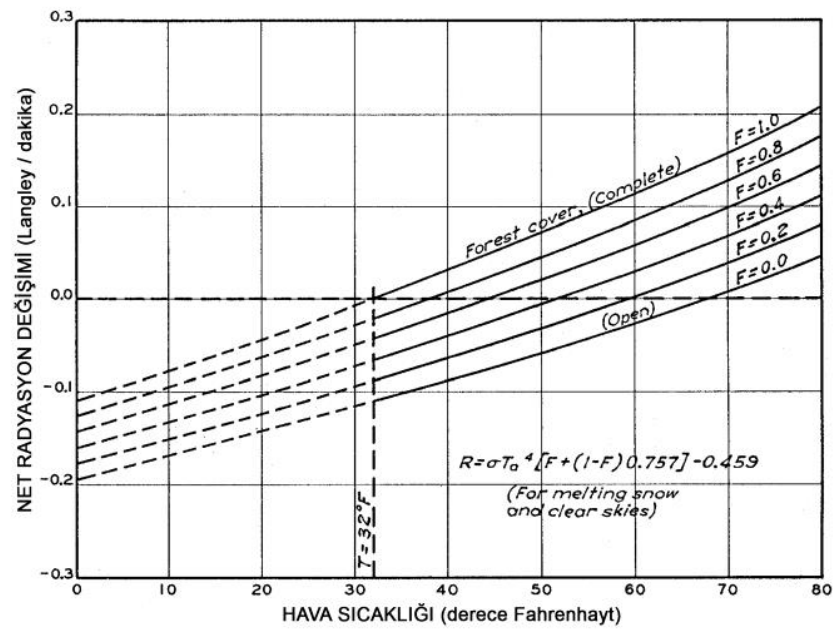

Şekil 2.3. SHADE etkisinin sicaklı̆ga bağlı olarak net uzun dalga radyasyon değişimine etkisi (Anonymous 1956)

LONG değeri donma noktasının üzerindeki hava sıcaklıkları için:

LONG $=$ SHADE $*, 26 *$ RELTMP $+(1,0-$ SHADE $) *(0,2 *$ RELTMP- 6,6$)$

donma noktası ve altında hava sıcaklıkları için:

LONG $=$ SHADE $* 0,20 *$ RELTMP $+(1,0-$ SHADE $) *(0,17 *$ RELTMP-6,6) $)$

RELTMP $=$ Hava sicaklığ $1-32\left({ }^{\circ} \mathrm{F}\right)$

6,6 = Açık alanlarda kar kütlesinden ortalama geri radyasyon kaybı (langley/aralık) 
denklemleri ile hesaplanır. Bu denklemdeki sabitler orijinal olarak saatlik zaman aralıklarına dayandığından, hesaplanmış değerlerin her ikisi de modelleme aralığı başına saatlerin sayısı (DELT60) ile çarpılır, böylece simülasyon zaman aralığına denk gelir. Ek olarak, modelde uzun dalga radyasyonunun negatif olduğu zaman dilimlerinde, bulutlardan yansıyan geri radyasyonu açılamak için, LONG değeri açık gökyüzü oranıyla (SKYCLR) çarpılır.

\subsection{2.f. Kütleden Ist Kaybı-COOLER}

Bu kodun amacı, kar kütlesinin çevresindeki havadan daha sıcak olduğu ve bu yüzden 1sı kaybettiği zaman diliminde kar kütlesini soğutmaktır. Bu durumda çıkan enerji kar kütlesinin negatif ısı kapasitesine aktarılır ve daha sonra kütleye 1sı girdiğinde WARMUP alt modülünde olduğu gibi erime gerçekleşmeden önce gelen 1sı ile bu kayıp tedarik edilir.

Atmosfere 1sı kaybının olduğu ve kar kütlesinin sıcaklığının hava sıcaklı̆̆ından fazla olduğu her aralıkta, negatif isı depolaması artacaktır; yani, kütle soğuyacaktır. Buna rağmen, maksimum bir ısı depolaması vardır. Her zaman olabilecek maksimum negatif isı depolaması, kar kütlesinin en altındaki tabakanın $32^{\circ} \mathrm{F}\left(0^{\circ} \mathrm{C}\right)$ olduğu varsayımıyla, bu sıcaklığın üzerinde olduğu düşünülen hava sıcaklığından itibaren kütlede lineer bir sıcaklık dağılımı gerçekleştiği farz edilerek bulunur. Bu maksimum negatif ısı depolaması saatlik olarak aşağıdaki gibi hesaplanır:

MNEGHS $=0,00695 *(\mathrm{PACKF} / 2,0) *(-\mathrm{RELTMP})$

MNEGHS = Maksimum negatif 1 sı depolaması (inç olarak su eşdeğeri)

PACKF $=$ Kar kütlesinin donmuş muhtevasının su eşdeğeri (inç)

RELTMP = Donmanın üstünde hava sıcaklı̆̆ $\left({ }^{\circ} \mathrm{F}\right)$

Negatif ısı depolamasının birikimi aşağıdaki ampirik denklemden saatlik olarak hesaplanır:

NEGHT $=0,0007 *($ PAKTMP-AIRTMP $) *$ DELT 60

NEGHT = Kar kütlesinin soğumasının potansiyel oranı (inç olarak aralık başına su eşdeğeri)

PAKTMP $=$ Kar kütlesinin ortalama sıcaklığ $1\left({ }^{\circ} \mathrm{F}\right)$

AIRTMP $=$ Hava sicaklı̆̆ $\left({ }^{\circ} \mathrm{F}\right)$

DELT60 = Modelleme aralığı başına saatlerin sayısı

NEGHT, MNEGHS tarafindan sınırlandırıldığı zamanlar haricinde negatif 1sı depolamasına (NEGHTS) her model zaman aralığında eklenir. NEGHTS, SNOW esas alt programında kar kütlesinin sıcaklığını hesaplamak için ve WARMUP alt programında kütlenin $32^{\circ} \mathrm{F}$ 'a ulaşmak için ısıtılması gereken büyüklüğü belirlemek için kullanılır.

\subsection{2.g. Kar Kütlesini Isttmak - WARMUP}

$\mathrm{Bu}$ alt program mümkün olduğu zaman kar kütlesini $32^{\circ} \mathrm{F}$ 'a kadar 1 sitır.

Kütlede negatif 1Sı depolaması (COOLER alt programındaki NEGHTS) ve önceki alt programlarda hesaplandığı gibi net giren enerji var olduğu zaman, NEGHTS, daha sıcak bir kar kütlesi ve muhtemel erime ile sonuçlanarak, azalacaktır.

$\mathrm{Bu}$ alt programda hesaplamalar sadece muhasebe edilir. NEGHTS değeri, net gelen ısının çıkartılmasıyla sıfır minimumuna kadar azaltılır. Şeyet, negatif ısı depolaması kalırsa, kütlye gelen herhangi bir yağmurun donmasıyla açığa çıkan gizli ısı kütleye eklenir. NEGHTS ve diğer bütün isı değişkenleri erimenin su eşdeğeri (inç veya $\mathrm{mm}$ ) cinsinden birimleri olduğundan kütle üzerine düşen yağmur yüksekliği (inç veya $\mathrm{mm}$ ) ve donma NEGHTS'den hiçbir değişim yapılmadan çıkarılır.

\subsection{2.h.Kalan Isı Kullanılarak Kütlenin Eritilmesi - MELTER}

MELTER, gelen ısının ne kadarı kaldıysa bununla kütlenin gerçek erimesini simüle eder. WARMUP alt programında kar kütlesini 1sıtmak için kullanılmayan herhangi bir 1sı, kar kütlesini eritmek için şimdi kullanılabilir.

$\mathrm{Bu}$ alt program sadece muhasebe yapan bir algoritmadır. Net gelen 1sı miktarı erimenin su eşdeğeri cinsinden önceden hesaplanmıştır. Bu yüzden, herhangi kalan gelen 1sı, kar kütlesinin boyutuna bağlı olarak ya kısmi olarak yada tamamen kar kütlesini eritmek için doğrudan kullanılır.

\subsection{2.i. Kütlede Sivı Su - LIQUID}

LIQUID alt programı öncelikle kar kütlesinin sıvı depolama kapasitesini belirler. Sonra, depolama kapasitesini doldurmak için ne kadar sıvı suyun mümkün olabileceğini belirler. Kapasite üstündeki sıvı, su eğer donmazsa kar kütlesinden ayrılır (ICING alt programı).

Kar kütlesinin sıvı su tutma kapasitesi, sıfirda veya kütlenin yoğunluğuna bağlı olarak arada bir yerde olabileceği gibi, MWATER parametresiyle belirlenen maksimum değerinde olabilir. Kar kütlesinin yoğunluğu ne kadar az ise tutma kapasitesi o kadar büyüktür. Aşağıdaki ilişkiler kapasiteyi tanımlar:

MNEGHS $=$ RDENPF $>0,91$ için,

$\mathrm{PACKWC}=0,0 \quad(2.19)$

$0,6<\mathrm{RDENPF}<0,91$ için, 
RDENPF $<0,61$ için,

PACKWC $=$ MWATER

PACKWC = Kar kütlesinin sıvı su tutma kapasitesi (inç/inç)

MWATER = Kar kütlesinin maksimum sıvı su muhtevasını belirleyen parametre (inç/inç)

RDENPF = Kar kütlesinin sıvı su yoğunluğuna oranı

MWATER, buz katmanı kütlesinin, kar kristallerinin boyut, şekil ve boşluğu ile kanallaşmanın derecesinin ve kar kütlesinin petekleşmesinin bir fonksiyonudur.

PACKWC bir kere hesaplandığında hâlihazırda kar kütlesindeki mevcut olan sıvı su miktarı (PWSUPY) ile karşılaştırılır. PWSUPY aralığın başındaki hâlihazırdaki depolama ile herhangi bir erime ve donmamış kütlenin üzerine düşen yağmur toplanarak hesaplanır. Eğer, PWSUPY değeri PACKWC'den daha fazlaysa, su kar kütlesinden arazi yüzeyine akar.

\subsection{2.j. Kütlede Buzun Meydana Gelmesi-ICING}

ICING alt programının amacı donmadı̆̆ taktirde kar kütlesinden ayrılacak suyun olası donmasını simüle etmektir. Sirasıyla bu donma kar kütlesinin altında buz veya donmuş zemin üretir. Bu alt programda buzun, kar kütlesinin altında olduğu veya kütlenin kar kısmının altında zemin içinde donmuş halde bulunarak toplam kütleyi zemine nüfuz ettirerek uzattığı düşünülebilir. Bu alt program sadece belirli alanlarda kabul edilebilir bu yüzden opsiyoneldir.

Kar kütlesinin su muhtevasının donması onu dondurmak için çevrenin kapasitesine bağlıdır. Her gün saat yaklaşık 6:00'da kapasite yeniden değerlendirilir. Yeni bir değer, havanın $32^{\circ} \mathrm{F}$ altındaki sıcaklarının Fahrenhayt derecelerinin 0,01 ile çarpılması yoluyla erimenin inç cinsinden tahminiyle yapılır. Bu mevcut tahmin şayet önceki 24 saatlik periyottan herhangi bir değer kalmışsa o donma kapasitesiyle karşılaştırılır. Eğer büyükse, yeni tahmin edilen kapasite eskisiyle yer değiştirir yoksa eski değer potansiyel olarak kalır. Kar kütlesini terk edebilecek herhangi bir su akışı donar ve kapasite karşılanıncaya kadar kar kütlesinin buz kısmına eklenir. Geriye kalan su akışı ise kar kütlesinden birakilır.

\subsection{2.k.Zeminden Gelen Isı Kullanılarak Kütlenin Erimesi - GMELT}

GMELT alt programının amacı kar kütlesinin altında bulunan yüzeyden iletilen ısının neden olduğu erimeyi simüle etmektir. Bu zemin ısısı kütleyi sadece alttan eritir. Bu yüzden bu işlemdeki erime, kar kütlesinin sıcaklığı yolu ile dolaylı bir etkisi hariç daha önce hesaplanmış ısı etkilerinden bağımsız düşünülür. Diğer erime işlemlerinden farklı olarak, zemin ısısı ilk olarak kar kütlesinin buz kısmını eritir çünkü buzun kar kütlesinin alt derinliklerinde olduğu düşünülür.

Zemin erimesinin potansiyel oranı kar kütlesi sıcaklığının (PAKTMP) ve yığışımlı (lumped) bir parametrenin (MGMELT) fonksiyonu olup, saatlik olarak hesaplanır. MGMELT $32^{\circ} \mathrm{F}$ 'lık bir PAKTMP'de zeminden iletilen 1 sının neden olduğu su eşdeğeri birimindeki maksimum erime oranıdır. MGMELT zeminin ısıl iletkenliğine ve normal zemin donma derinliğine bağlıdır.

MGMELT parametresinden azaltılan potansiyel zemin erimesi miktarı PAKTMP'nin $32^{\circ} \mathrm{F}$ altındaki her bir Fahrenhayt derecesinin \%3'ü mertebesinde olup minimal değeri toplamda 5 Fahrenhayt veya daha düşük sıcaklıklarda MGMELT'i \%19'una kadar azaltabilir. Kar kütlesi olduğu sürece zemin erimesi bu potansiyel oranda meydana gelir.

\subsection{2.l. Kar Kütlesi Kaybolduğu Zaman Durum Değişkenlerini Sıfırlamak-NOPACK}

$\mathrm{Bu}$ kod, kar kütlesi tamamen kaybolduğu zaman durum değişkenlerini (örneğin SNOCOV) sıfirlar (resetler).

Karın alansal örtüsü (COVINX) için gerekli olan kar kütlesinin donmuş muhtevası arazinin tamamen karla kaplı olduğu varsayılan maksimum değerin (COVIND) onda birine ayarlanır. Diğer bütün değişkenlere ya sıfır yada -1,0E30 tanımsız değeri atanır.

\section{Araştırma Sonuçları ve Tartışma}

\subsection{Veri Analizi}

BASINS sisteminin çekirdeğini oluşturan HSPF modeli ile Kırkgöze Havzası ve alt havzalarının hidrolojik benzetimlerini etkili bir şekilde ortaya koyabilmek adına havzada kar erimesinin etkili olduğu göz önüne alınmış olup, havzanın su ve enerji dengesini karakterize etmek için daha önceden yapılan çalışmalarla (Şengül, 2011) havza alanına ait Sayısal Yükseklik Modeli (SYM) haritası, Akarsu ă̆ı haritası, Arazi kullanım haritası (bitki örtüsü), Zemin özellikleri haritası, Jeoloji ve hidrojeoloji haritası, Yükseklik zonları haritası, Eğim ve bakı haritaları, Güneş radyasyonu dağılım haritası, Alt havza sınırları haritası, Karla kaplı alanlar için uydu görüntüleri verileri bilgisayar ortamında Coğrafi Bilgi Sistemleri kullanılarak birbiri ile ilişkilendirilmiş ve analiz edilerek havza karakterizasyonu gerçekleştirilmiştir.

Havzanın 1/25000'lik topoğrafik haritaları optik tarayıcı ile taranarak bilgisayar ortamına raster formatında aktarılmıştır. Bu raster veriler UTM koordinat sistemine uygun olarak jeoreferanslanmış ve dünya üzerindeki gerçek yerine oturtulmuştur. Bu haritalar üzerindeki eş yükselti eğrileri ve akarsu yatakları el ile sayısallaştırılmış, arazide GPS cihazı ile yapılan çalışmalar sonucunda zamanla değişen akarsu yatakları tespit edilmiş ve TNTMips programı kullanılarak havzaya ait SYM elde edilmiştir. SYM'ne yüzey eklenerek arazinin 3 boyutlu görüntüsü elde edilmiştir (Şekil 3.1 ve Şekil 3.2). 
Havza genelinde mekânsal olarak farklılık gösteren alanlar arazi topoğrafyasının ve havzanın hidrojeolojik davranışının kurulan kar erime modeli üzerinde etkili olduğu bilinen birtakım kriterler esas alınarak belirlenmiştir. Buna göre ilk olarak tüm havza geneli 6 farklı tasnif metoduna göre farklı katmanlar halinde BASINS ortamında yardımcı CBS yazılımları ile desteklenerek karakterize edilmiştir (Yükseklik Zonları (6’lı Sınıflandırma), Erime dönemi güneş açısına göre arazinin Solar Radyasyon Dağılımı (5'li sınıflandırma), Hidrojeolojik Toprak Katmanları (8'li sınıflandırma), Alt Havzalar (7'li sınıflandırma), Arazi Eğimi (2'li sınıflandırma: 0-15,3 , 15,3-45 derece), Arazi Kullanımı (9'lu sınıflandırma)). Katmanların daha sonra üst üste bindirilmesi ile ilk etapta değişik eş karakteristiklere sahip toplam 491 adet poligonal arazi sınıflandırması oluşmuştur. Kurulacak hidrolojik modelde parametre sayısını azaltmak adına bir optimizasyon algoritması geliştirilerek tüm havza alanının \%2 lik kısmını ifade eden 193 adet küçük poligon alanları kendilerine sınırca en büyük poligon alanına dahil edilmiş ve böylece nihai olarak Kırkgöze havzası, toplamda 309 farklı eş karakteristik yapı ile ifade edilmiştir. Bu çalışmada havzada farklı karakteristik noktalara kurularak işletilen 3 adet meteoroloji ve kar gözlem istasyonlarınin bulunduğu 3 farklı eş karakteristikli poligonal arazi alanı üzerinde gerekli inceleme ve tahminlerde bulunulacaktır (Şekil 3.3). Yani istasyonlardan noktasal olarak alınan meteorolojik ham veriler kar kütlesinin üzerinde bulunduğu arazinin alansal homojenitesi ile beraber değerlendirilmektedir. Böylelikle özellikle dağlık alanlarda oldukça değişken yüzey topoğrafyasının erime üzerindeki etkileri de daha anlaşılır olacaktır. Örneğin istasyonlar normal olarak tesviye edilmiş düz bir arazi üzerinde konumlandırılmış olsalar da tümleşik kar kütlesinin dinamiklerine etki eden arazi yüksekliği, ortalama arazi eğimi, arazi kullanımı vb. diğer değişkenlerin de başka eş karakteristikli arazi yapıları ile olan uyumu ve ilişkisi de incelenebilir olmaktadır. Böylelikle ileride yapılacak olan diğer geniş kapsamlı kar erimesi-akış çalışmalarında karakteristik özelliği bilinen göreceli olarak noktasal ölçekten elde edilen kar parametrelerinin manipülasyonuna imkân tanınarak elde edilen parametrelerin gerçek anlamda havza üzerindeki alansal dağılımına geçiş imkânı sağlanmış olacaktır. Bu noktada çalışmada kullanılan yöntemin 3 farklı özellikteki istasyon konumundan elde edilen sonuçları kavramsal olarak ilişsilendirebilmesi de ayrıca önemlidir.

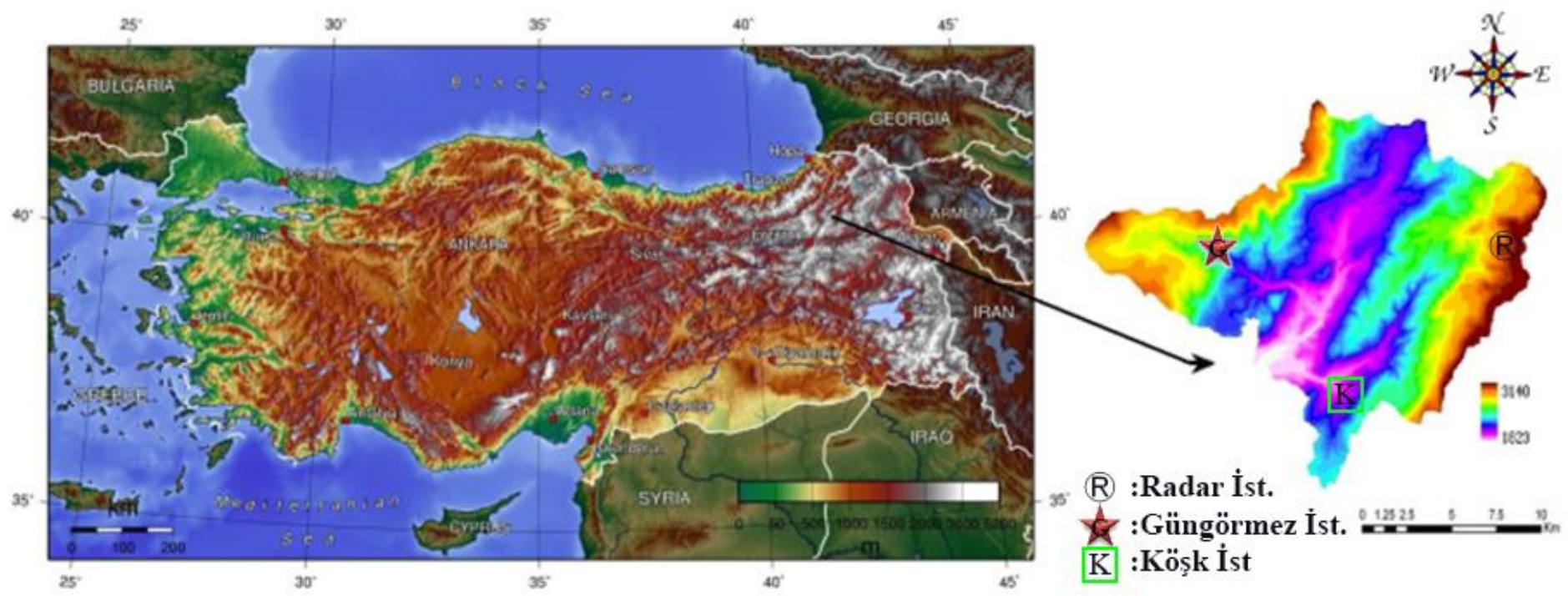

Şekil 3.1. Çalışma alanı (Kırkgöze Havzası) eş yükselti haritası ve istasyon konumları

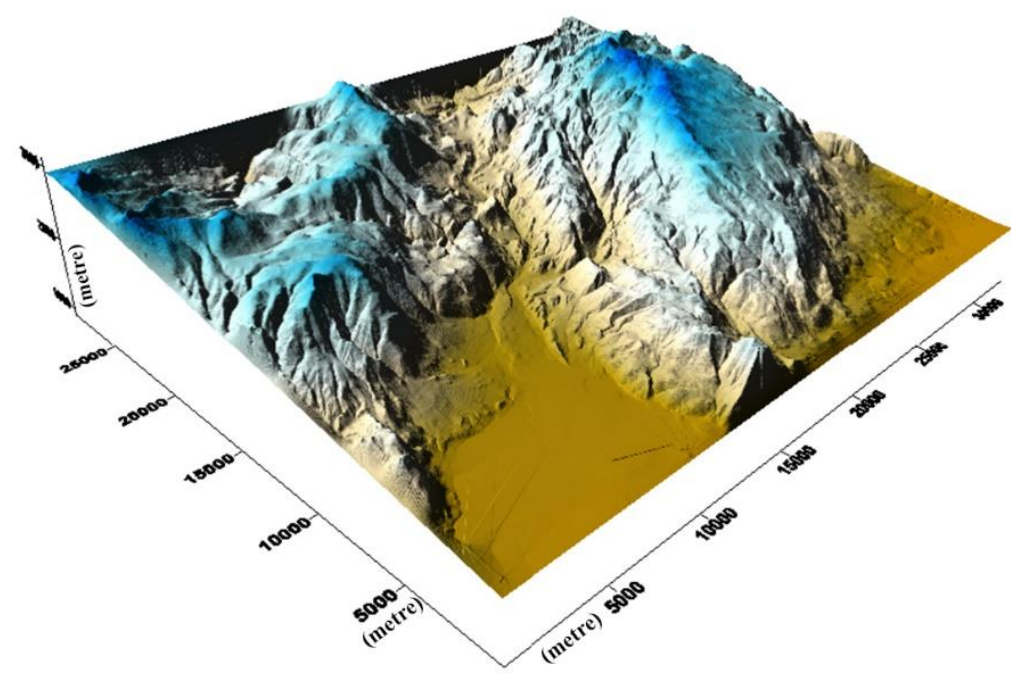

Şekil 3.2. Havzanın SYM'den elde edilen 3 boyutlu görüntüsü

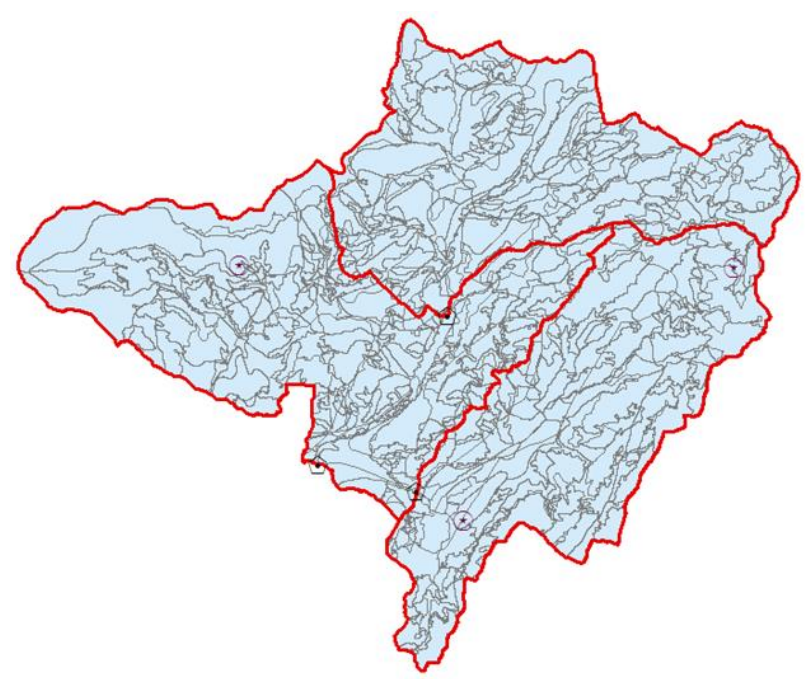

Şekil 3.3. Nihai eş karakteristikli poligon sınıflandırması 


\subsection{Meteorolojik Veriler}

HSPF model programı hidrolojik süreçlerin arkasındaki itici güç olarak meteorolojik zaman serilerine gerek duymaktadır.

HSPF model programı, kar erimesinin etkili olduğu havzalarda enerji dengesi metodu ile hidrolojik modelleme yapabilmek için Tablo 3.1'de verilen 7 meteorolojik zaman serisine ihtiyaç duymaktadır.

Tablo 3.1. HSPF'de enerji dengesi metodu ile kar simülasyonlarını gerçekleştirebilmek için kullanılan meteorolojik zaman serileri

\begin{tabular}{c}
\hline Zaman Serileri \\
\hline Hava sıcaklığı \\
Çiğ noktası sıcaklığı \\
YağıŞ \\
Bulutluluk (Opsiyonel) \\
Rüzgâr hızı \\
Potansiyel evapotranspirasyon \\
Güneş 1şıması (solar radyasyon) \\
\hline
\end{tabular}

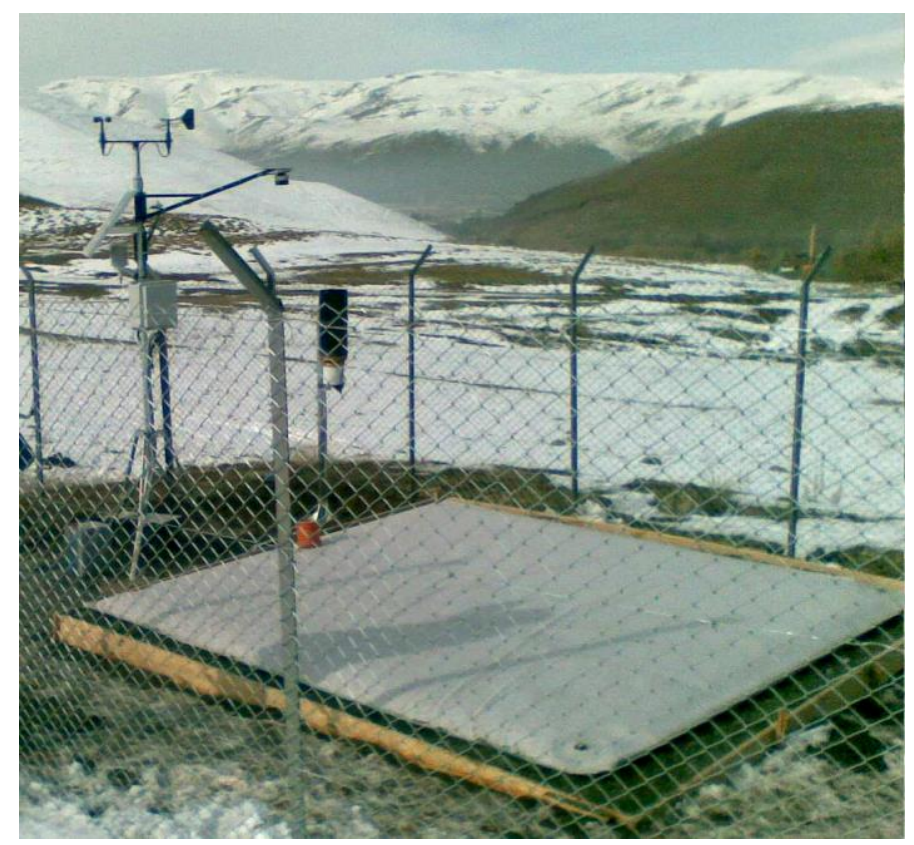

Şekil 3.4. Köşk Köyü meteoroloji ve kar gözlem istasyonu

HSPF model programı 5 dakikaya kadar inebilen aralıklarla modelleme gerçekleştirebilmektedir. Literatürde havza çalışmalarında genellikle saatlik zaman aralıklarında veriler kullanılarak modelleme yapılmıştır. Kırkgöze (Çipak) havzasının dağlık bir alan olması ve kar erimesinin gün içerisindeki salınımlardan önemli ölçüde etkilendiği göz önüne alındığında meteoroloji istasyonlarından alınan 15'er dakikalık çözünürlükteki veri simülasyon süresinin optimum bir bakış açısıyla kısaltılması ve değişkenler arasındaki kavramsal ilişkinin kaybolmaması amacıyla 1'er saatlik çözünürlüğe indirgenerek kullanılmıştır.

Havzada belirlenen 2019 m, 2454 m ve 2891 m yüksekliklerdeki uygun yerlere üç adet otomatik meteoroloji ve kar gözlem istasyonları önceden kurulmuştur olup sensörler güncellenerek bakımları gerçekleştirilmektedir (Şekil 3.4). Kar potansiyeli yüksek olan dağlık bir havza içerisindeki farklı bakı ve yüksekliklerde üç istasyondan alınan iklim verilerinin yeterli, kaliteli ve gerçek zamanlı toplanabildiği gösterilmiştir (R Acar, Şenocak, \& Şengül, 2009; R. Acar, Şenocak, Şengül, Coşkun, \& Balık Şanl1, 2009).

Otomatik meteoroloji istasyonları ve kar yastığı yardımıyla gün içerisinde her 15 dakikalık dilimler için maksimum rüzgâr hızı (m/sn), rüzgâr yönü, hava basıncı (mbar), ortalama hava sıcaklığ $1\left({ }^{\circ} \mathrm{C}\right)$, ortalama hava nemi $(\% \mathrm{rh})$, ortalama toprak sıcaklığı $\left({ }^{\circ} \mathrm{C}\right)$, Güneş radyasyonu $\left(\mathrm{W} / \mathrm{m}^{2}\right)$, ortalama albedo, yağış $(\mathrm{mm})$, kar yüksekliği $(\mathrm{cm})$, kar yoğunluğu $\left(\mathrm{gr} / \mathrm{cm}^{3}\right)$ ve kar su eşdeğeri $(\mathrm{cm})$ verileri GSM haberleşme cihazı yardımıyla alınmaktadır. Gözlem istasyonlarından elde edilen meteorolojik veriler 15'er dakikalık zaman periyotlarında kaydedilmektedir. Erzurum Kırkgöze (Çipak) havzasında 2891 metrede kurulmuş olan Radar otomatik meteoroloji ve kar gözlem istasyonundaki iklim koşulları Aralık 2007 ile Temmuz 2009 zaman aralığı için karşılaştırmalı olarak değerlendirilmiştir (Şenocak, 2011). Benzer bir çalışma Aralık 2007 ile Haziran 2008 zaman aralığı değerleri için de yapılmıştır (R. Acar et al., 2009).

\subsection{HSPF Modelinde Hava Sıcaklığı Yükseklik Farkı (ATEMP) ile İlgili Analizler}

Her bir poligon alanının ölçüm yapılan istasyonla arasındaki yüksseklik farkı (ELDAT) CBS ile hesaplanmış ve iterasyona başlamak için simülasyon başlangıcında her bir poligonun başlangıç hava sıcaklıkları yüksekliğe bağlı olarak elde edilmiştir. Bu çalışmada istasyonların bulunduğu arazi üzerinde noktasal olarak modelleme yapıldığından ELDAT değerleri sıfır özgün değerine indirgenmiştir. 


\subsection{HSPF Modelinde İstasyonlardaki Kar, Buzlanma ve Erime Süreçleri ile İlgili Analizler}

Geçirimli arazi parçaları için HSPF benzetimleri yapılırken kar ile ilgili işlemlerin araziyi en iyi şekilde karakterize etmesi için bir takım giriş parametrelerine ihtiyaç duyulur. Bölüm 2.2'de kar ile ilgili süreçlerin birbiri ile kavramsal olarak ilişkilendirilmesi ve ilgili bölgede değişkenlerin birbirlerini hangi oranda etkilediğinin belirlenebilmesi için modelde bu bölümde bahsedilen bir takım parametrelerin farklı yıllarda kalibre edilerek özgün ve güvenilir değerler alması gerekmektedir. Çalışmada noktasal ölçekte istasyon lokasyonlarından elde edilen bu parametreler 2008-2009, 2009-2010 kar periyodunda kalibre edilmiş (Şengül, 2011) ve 2010-2011 yılında ölçülen değerler ile yeniden güncellenerek valide edilmiştir. Nihai olarak meteoroloji istasyonları ve kar yastıklarından gözlemlenen kar yüksekliği ve kar su eşdeğeri verileri ile kalibre edilen noktasal ölçekteki parametreler belirli bir sistematik doğrultusunda araziye dağıtılarak gerçek havza davranışı akım gözlem istasyonlarından ölçülen debi değerleri ile karşılaştırılarak havzanın su bütçesi hesabına geçilebilir. Bu çalışmada su bütçesi kalibrasyon yönteminin hesap detaylarına değinilmemiştir.

SNOW modülünde arazi ve kar yapısını karakterize edebilmek için ICE-FLAGS, SNOW-FLAGS, SNOW-PARM1 ve SNOWPARM2 tablolarının her bir eş karakterli poligon alanı için işlenmesi ve kalibre edilmesi gerekmektedir.

\subsubsection{ICE-FLAGS Tablosu}

Bu tablo ile her bir arazi parçasında biriken kar kütlesi içinde buz formasyonunun oluşup oluşmadığı ve buna bağlı olarak ICING modülünün çalıştırılıp çalıştırılmayacağı komutu girilir. "1" girdisi ile kar kütlesinin taban kısmında buzlanma olduğu, "0" girdisi ile arazide buzlanmanın olmadığı ve dolayısıyla zeminde de infilitrasyon özelliğine etki edecek herhangi bir donmanın olmadığı belirtilir.

Çalışma alanının yüksek rakımlı dağlık bir alan olması nedeniyle bütün istasyon alanlarında buzlanma (ICING) modülü etkinleştirilmiştir. Ayrıca, arazi gözlemleri esnasında kar tüpü ile alınan karotların alt kısımlarında buzlanma olduğu da belirlenmiştir.

\subsubsection{SNOW-FLAGS Tablosu}

Bu tablo ile modellemenin derece-gün yöntemi (sıcaklık indeksi yöntemi) ile mi yoksa enerji dengesi metodu ile mi yapılacağını belirten anahtarlar vardir.

Bu çalışmada kar ile ilgili modellemeler enerji dengesi metodu seçilerek yürütülmüştür.

\subsubsection{SNOW-PARM1 Tablosu}

$\boldsymbol{L A T}$-Latitude: LAT parametresi girişi çalışma havzasının enlemini ifade eder. Kuzey yarım küre için pozitif, güney yarım küre için negatif değerler alır. Modelde mevsim aralıklarının tayini için kullanılır ve yüzey albedosunun alabileceği maksimum ve minimum değerlere etki eder.

Kırkgöze havzası 40. enlemde bulunduğundan bütün arazi parçalarına 40 değeri girilmiştir.

MELEV-Mean Elevation: Atmosferden kar kütlesine konvektif 1sı akışını hesaplamak için kullanılan bir parametredir. Her bir arazi parçasının deniz seviyesinden yüksekliğinin feet biriminden ifadesidir.

Her bir istasyonu barındıran poligon alanının ortalama rakımları, CBS araçları kullanılarak SYM haritasından elde edilip tabloya işlenmiştir.

SHADE: Her bir arazi parçasının ağaçlar veya yamaçlardan ötürü gölgelenme oranınıdır. SHADE kar kütlesine ulaşan güneş radyasyonunu kontrol eder. Ayrıca modelde Stefan'ın Siyah Cisim Yasası'na dayanarak uzun dalga radyasyon hesaplamalarında kullanilır.

SHADE, başlangıçta 0 değeri ile modellemeye başlanmış olup daha sonra kar yastıklarından elde edilen kar yüksekleri ve kar su eşdeğeri verileri, simülasyon sonuçları ile karşılaştırılmıştır. Gerçekleştirilen kalibrasyonlar sonucunda Köşk, Güngörmez ve Radar istasyonları için sırasıyla 0,43, 0,6 ve 0,72 değerleri bulunmuştur. SHADE parametresi SNOW modülünde net kısa dalga radyasyonu hesaplanırken bir albedo düzeltme katsayısı olarak işlev görmektedir (Denklem 2.14).

SHADE parametresi 1'e yaklaştıkça, kar yüzeyinin gelen kısa dalga radyasyonunu yansıtması artacak ve kütleye tesir eden net kısa dalga radyasyon miktarını azaltacaktır. Farklı yüksekliklerdeki istasyonlardan kalibrasyon ile elde edilen değerlerin üst kotlara çıkıldıkça artması, dağlık alanlarda yüksek rakımlarda kısa dalga radyasyonun daha az etkili olmasının bir göstergesidir. Bu durumun ayrıca, dağlık alanlarda düşük kotlardaki erken erime neticesinde açığa çıkan yüzeysel kirliliğin rüzgârlarla kar kaplı alanların üzerine taşınması ile yüzey kirliliğinin alt kotlardan üst kotlara doğru azalmasının bir sonucu olduğu da düşünülebilir.

SNOWCF-Snow Coeffcient: Rüzgâr kalkanı olmayan yağışölçerlerde yağışın kar şeklinde olması durumunda, rüzgâr hızına ve yağışölçerin yapısına bağlı olarak yağışın bir kısmının ölçüm haznesine girmeyeceği belirtilmiştir. Bu durumda, kar olarak yağan yağış SNOWCF ile belirtilen bir düzeltme katsayısı ile çarpılır.

$\mathrm{Bu}$ çalışmada, istasyonlarda bulunan yağışölçerlerin yüksek yağış ve aşırı soğuk nedeniyle kış aylarında etkin bir şekilde kullanılamamasından ötürü, yağış miktarları kar yastığından alınan kar su eşdeğerleri ile simüle edilmiştir. Dolayısıyla bu katsayı bütün arazi parçalarında 1 olarak alınmıştır.

COVIND-Cover Index: Arazi parçasının tümü karla kaplandığında arazi parçasındaki maksimum kar yüksekliğinin, su eşdeğeri olarak yüksekliğidir (inç). COVIND arazi topolojisinin ve iklim koşullarının bir fonksiyonudur. ARM modeli kullanma kılavuzunda (Donigian \& Davis, 1978) eşdeğer bir parametre olan MPACK değişkeni için 1-6 inç arasında değerler önerilmiştir. Düzlük alanların daha fazla olduğu ve kar yağışının etkin olduğu arazilerde genellikle alt sınıra yakın değerler kullanılmaktadır. Dağlık havzalarda ise, 
arazinin tamamen karla kaplanması için çok daha fazla kar yağışı gerektiğinden COVIND değeri üst sınıra yakın olur. COVIND su eşdeğeri cinsinden girildiği için 1 inçlik bir değer esasen yaklaşık 10 inçlik kar yüksekliğine karşllık gelmektedir.

\subsubsection{SNOW-PARM2 Tablosu}

RDCSN: Hava sıcaklığı 0 derece Fahrenhayt $\left(-17,78^{\circ} \mathrm{C}\right)$ veya daha düşük sıcaklıklarda iken yeni yağan kar yoğunluğunun suyun yoğunluğuna oranıdır. Tahmini bir değerle simülasyona başlandıktan sonra kalibre edilmesi gereklidir. Kalibrasyon yapılırken arazi verilerinden elde edilen kar yüksekliği ve kar yoğunluğu değerleri analiz edilir. RDCSN parametresi model çalışırken hava sıcaklığına bağlı olarak otomatik olarak yeniden hesaplanır. Kar yoğunluğu/sıcaklık bağıntısı B. R. Bicknell, Imhoff, Kittle Jr, Donigian Jr, and Johanson (1997) tarafindan açıklanmıştır.

İstasyonlarda kar yastığından elde edilen veriler ışığında kar yüksekliği ve kar yoğunluğu değerleri göz önüne alınarak kalibrasyon yapılmıştır. Köşk, Güngörmez ve Radar istasyonları için sırasıyla $0,14,0,16$ ve 0,16 değerleri bulunmuştur.

TSNOW: Doygun şartlarda yağışın hangi ıslak termometre sıcaklı̆̆ının altında kar olarak yağdığını belirten bir parametredir. Derece Fahrenhayt olarak girilir. Tahmini bir değerle simülasyona başlandıktan sonra kalibre edilmesi gereklidir. Literatürde 31-33 derece F arasında değerler kullanılmıştır (Donigian \& Davis, 1978). Hava sıcaklığı TSNOW eşiğini aştığı zaman yağmur yağışı, aksi takdirde kar yağışı olarak simüle edilir. HSPF simülasyonlarında TSNOW eşiği olarak 30 40 derece Fahrenhayt $\left(-1,11 \sim+4,44^{\circ} \mathrm{C}\right)$ arasında değer girilebilir. Başlangıç değeri olarak $32^{\circ} \mathrm{F}\left(0^{\circ} \mathrm{C}\right)$ ile simülasyona başlanması önerilmektedir. Crawford (1999)'a göre TSNOW kar birikmesine etki eden en önemli parametrelerden birisidir. Her halükârda TSNOW parametresi 32 derece Fahrenhayt civarında yağan yağışların simülasyonunda önem arz eder. Şayet kış aylarında tipik kar yağışı 30 derece $\mathrm{F}\left(-1,11^{\circ} \mathrm{C}\right)^{\prime} ı n$ altında oluşuyorsa TSNOW’un etkisi küçük veya önemsenmeyecek kadardır.

Özellikle erime döneminin sonlarında etkisi açıkça gözlenen TSNOW parametresi, istasyonlardaki kar yükseklikleri ve kar su eşdeğerlerinin değişimi incelenerek analiz edilmiş̧ir. Kalibrasyonlar sonucunda yağmurdan ötürü meydana gelen kar yüksekliğindeki ani değişimler gözlenmiş verilere uygun olarak simüle edilmiştir. Kuzey bakısına sahip Köşk ve Radar istasyonlarında sırasıyla $36^{\circ} \mathrm{F}$ $\left(2.22^{\circ} \mathrm{C}\right)$ ve $40^{\circ} \mathrm{F}\left(4.44^{\circ} \mathrm{C}\right)$, güney bakısına sahip Güngörmez istasyonunda ise $31,6^{\circ} \mathrm{F}\left(-0.22^{\circ} \mathrm{C}\right)$ değerlerleri elde edilmiştir. Simülasyonlarda TSNOW parametresinin maksimum değeri $40^{\circ} \mathrm{F}$ 'dır.

SNOEVP: Kar kütlesinden süblimleşme ile evaporasyonun ölçüsünü ayarlayan birimsiz bir parametredir. Literatürde 0,1 civarındaki değerlerin kabul edilebilir olduğu gösterilmiş̧ir (Donigian \& Davis, 1978). Kar kütlesinden evaporasyon havanın buhar basıncının kar yüzey basıncından daha az olduğu zaman gerçekleşir (B. R. Bicknell et al., 1997). Evaporasyon, rüzgâr hızının ve karla kaplı arazi yüzdesinin bir fonksiyonu olarak, kar kütlesinin sadece donmuş olan kısmından gerçekleşir. Kar evaporasyonu çoğu havzada büyük ölçülerde olmaz ancak rüzgârlı ve düşük nemli şartlar altında etkilidir (Crawford, 1999).

Kırkgöze havzası için kar yüksekliği ve kar su eşdeğeri simülasyonlar sonucunda kalibre edilerek, tüm istasyonlar için 0,05 değeri kullanılmıştır.

CCFACT: Kar Arazi şartlarına göre atmosferden kar kütlesine konveksiyon ve kondansasyon yoluyla 1sı transferinin oranını belirleyen birimsiz bir parametredir. Tahmin edilerek kalibrasyonu gerçekleştirilir. CCFACT iklim şartlarının bir fonksiyonudur. Rüzgâr hızı ve hava sıcaklığı değişkenleri ile 1sı transferini modeller. Literatürdeki tipik değeri 1,0 civarında olup, genelde 0,5 ile 2,0 arasında değerler gözlenmiştir. HSPF simülasyonlarında 0,5-8 arasında değer alabilmektedir.

Kar erimesinde çok etkili bir parametre olan erime oranının bir ifadesi olan CCFACT parametresi erime zamanının tayininde etkilidir. İstasyonlardaki kar erimesi ve kar yüksekliğindeki değişim gözlenerek kalibre edilmiştir. Köşk, Güngörmez ve Radar istasyonları için sırasıyla $0,5,1,7$ ve 2,0 değerleri bulunmuştur. CCFACT değeri arttıkça erime dönemi zamanda ötelenmektedir.

MWATER: Kar kütlesindeki maksimum sıvı su tutma kapasitesidir (inç/inç). MWATER, kar kütlesinde biriken suyun sızmasını engelleyen buz katmanları ile kar kristallerinin boyut, şekil ve boşluğunun; ayrıca, kütledeki kanallaşma derecesi ve petek örgüsünün bir fonksiyonudur. Literatürde deneysel sonuçlar ile elde edilen bu değer 0,01 'den 0,05 'e kadar değişim gösterirken genelde 0,03 ortalama değeri alınır (Donigian \& Davis, 1978). HSPF modelinde minimum 0,005 ile maksimum 0,2 aralığında fiziksel olarak anlamlı bir aralıkta kullanılabilmektedir.

Kar yastıklarından elde edilen kar su eşdeğeri birikme ve çekilme eğrilerinin karakteristik simülasyonu; ancak, MWATER parametresinin ekstrem bir değeri olan 0,2 değerini aldığında gerçek değerler ile örtüşmektedir. Bu durum dağlık alanlarda gün içindeki 1S1 değişiminin fazla olması neticesinde, kar kütlesinin katman katman tabakalaşması sonucunda kütle içindeki serbest suyu bırakmaması ile açıklanabilir. Ayrıca erime döneminde yapılan arazi gezilerinde, erimeye başlayan kar kütlesinin neredeyse yarım metreye yakın kısmının su kıvamında olduğu gözlenmiş, kar hediği takılmasına rağmen bazı yerlerde yürümenin neredeyse imkânsız hale geldiği tecrübe edilmiştir.

MWATER parametresi bütün havzada 0,2 olarak dağıtılmıştır.

MGMELT: Zemin ısısından ötürü meydana gelen maksimum günlük kar erimesini ifade eden bir parametredir (inç/gün). MGMELT oranı kar kütlesinin sicaklığ 32 derece $\mathrm{F}\left(0^{\circ} \mathrm{C}\right)$ olduğu zaman simülasyona dâhil olur.

Zeminden kar örtüsünün tabanına 1sı iletimi genellikle erime için oldukça küçük bir enerji kaynağıdır. Bu 1sı akışı karın üzerinde bulunduğu zeminden kar örtüsüne doğru hareket eder. Zeminde kar örtüsü yokken yaz dönemi boyunca zemin tarafından depolanarak kar örtüsünün erimesine katkıda bulunan enerji, kış ve baharın ilk dönemlerinde kar tabanının altında erimeye neden olur (Anonymous, 1998; Singh \& Singh, 2001). Kar örtüsünün erime döneminde zeminden kaynaklı erimenin 0,05 cm/gün alınması önerilir (Anonymous, 1956). MGMELT parametresi bütün çalışma havzasında 0,02 inç/gün $(0,0508 \mathrm{~cm} /$ gün $)$ olarak dağıtılmıştır.

e-ISSN: 2148-2683 


\subsection{ATEMP ve SNOW Parametreleri ve Değer Aralıkları}

HSPF simülasyonlarında kullanılan ATEMP ve SNOW modüllerinin kullanıcı tanımlı giriş parametreleri ve sınır değerleri Tablo $3.2^{\prime}$ de gösterilmiştir. Modelleme yapılırken kalibrasyon değerleri verilen aralıklarda girilmiş̧ir.

Tablo 3.2. ATEMP ve SNOW modüllerinin kullanıcı tanımlı giriş parametreleri ve sınır değerleri

\begin{tabular}{|c|c|c|c|c|c|c|}
\hline \multirow{3}{*}{ ADI } & \multirow{3}{*}{ BİRİM } & \multicolumn{4}{|c|}{ DEĞER ARALIKLARI } & \multirow{3}{*}{ FONKSIYYON } \\
\hline & & \multicolumn{2}{|c|}{ GENEL } & \multicolumn{2}{|c|}{ OLASI } & \\
\hline & & ALT & $\ddot{\text { ÜST }}$ & ALT & ÜST & \\
\hline \multicolumn{7}{|c|}{ ATEMP - DAT } \\
\hline ELDAT & feet & -1000 & 1000 & - & - & Topoğrafya, istasyon konumu \\
\hline AIRTMP & ${ }^{\circ} \mathrm{F}$ & 30,0 & 70,0 & 0 & 90,0 & İklim \\
\hline \multicolumn{7}{|c|}{ SNOW-PARM 1} \\
\hline LAT & derece & 30 & 50 & -90 & 90 & Konum \\
\hline MELEV & feet & 50 & 3000 & 0 & 7000 & Topoğrafya \\
\hline SHADE & - & 0.1 & 0.5 & 0 & 0,8 & Orman oranı, topoğrafya \\
\hline SNOWCF & - & 1,1 & 1,5 & 1,0 & 2,0 & Yağışölçer tipi ve konumu \\
\hline COVIND & inç & 1,0 & 3,0 & 0.1 & 10 & Topoğrafya, iklim \\
\hline \multicolumn{7}{|c|}{ SNOW-PARM 2} \\
\hline RDCSN & - & 0,1 & 0,2 & 0,05 & 0,3 & İklim, hava sıcaklığ1 \\
\hline TSNOW & ${ }^{\circ} \mathrm{F}$ & 31 & 33 & 30 & 40 & İklim, hava sıcaklığ \\
\hline SNOEVP & - & 0,10 & 0,15 & 0 & 0,5 & İklim, hava sıcaklığ \\
\hline CCFACT & - & 1,0 & 2,0 & 0,5 & 8,0 & İklim \\
\hline MWATER & inç/inç & 0,01 & 0,05 & 0,005 & 0,2 & İklim \\
\hline MGMELT & inç/gün & 0,01 & 0,03 & 0 & 0,1 & İklim, jeoloji \\
\hline
\end{tabular}

\subsection{PWATER Su Bütçesi Parametreleri}

Çalışmada kar kütlesinden salınan serbest su miktarının (WYIELD) ilgili zaman diliminde varsa yağmur yüksekliği ile toplanarak istasyon konumlarındaki eş karasteristikli arazi parçaları üzerinde oluşturacağı yüzeysel ve iç akış yüksekliklerinin (SURO ve PERO) hesaplanmasında kullanılan PWATER parametreleri modelde kullanıldığı İngiliz birim sistemi orjininde Tablo 3.3 'de verildiği üzere özetlenebilir. Konu ile ilgili olarak detaylı bilgi için HSPF kullanım klavuzuna (B. Bicknell, Imhoff, Kittle Jr, Jobes, \& Donigian Jr, 2001) başvurulabilir.

Tablo 3.3. PWATER Su Bütçesi Parametreleri

\begin{tabular}{|c|c|c|c|c|c|c|c|c|c|c|c|c|c|c|}
\hline 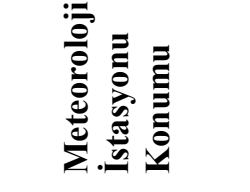 & $\begin{array}{l}\stackrel{0}{Z} \\
\vdots \\
\stackrel{000}{0} \\
0\end{array}$ & 爰 & 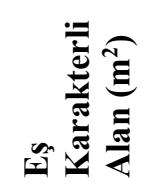 & 芯 & 赇 & $\underset{3}{5}$ & 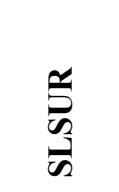 & $\frac{\vec{z}}{4}$ & $\underbrace{u}_{\substack{u\\
}}$ & $\begin{array}{l}Z \\
\text { ZN } \\
\text { S }\end{array}$ & $\begin{array}{l}\text { 光 } \\
\text { Z }\end{array}$ & $\vec{z}$ & $\underset{\Xi}{\cong}$ & $\stackrel{7}{\mathrm{~N}}$ \\
\hline KÖŞK & 305 & $\begin{array}{l}\text { Kuru } \\
\text { Tarım }\end{array}$ & 835601 & 8.5 & 0.16 & 147 & 0.18 & 0.5 & 0.995 & 0.68 & 0.2 & 1 & 0.65 & 0.6 \\
\hline GÜNGÖRMEZ & 120 & $\begin{array}{l}\text { Değissisim } \\
\text { Alanı }\end{array}$ & 3522320 & 8.5 & 0.05 & 50 & 0.293 & 0.5 & 0.995 & 0.51 & 0.2 & 1 & 0.38 & 0.6 \\
\hline RADAR & 404 & $\begin{array}{l}\text { Değissisim } \\
\text { Alanı }\end{array}$ & 2924080 & 15 & 0.07 & 64 & 0.131 & 0.5 & 0.995 & 0.595 & 0.2 & 1 & 0.61 & 0.6 \\
\hline
\end{tabular}

\section{7. İklim Değişikliği Parametreleri}

Güventürk (2013) 'İklim Değişikliğinin Türkiye’nin Doğusunda Dağlık Alanlardaki Su Kaynaklarına Etkisi’ isimli çalışmasında Türkiye'nin doğusundaki dağlık alanlarda (Şekil 3.5) meteorolojik verilerin 40 y1llık trend analizlerini gerçekleştirmiş ve ilgili istasyonlarda sıcaklık ve yağış trendlerini yıllık ortalama, kar birikme sezonu ve kar erime sezonu için farklı istatistik metodlar (nonparametrik Mann-Kendall ve Spearman's Rho testi) kullanarak ortaya koymuştur. Yapılan bu çalışma daha sonra aynı bölgedeki nehir akımlarının trendleri de incelenerek kapsamı genişletilmiştir (Yucel et al., 2015). Çalışmada kullanılan meteoroloji istasyonlarının isimleri, data periyotları ve yükseklikleri Tablo 3.4 'de sunulduğu gibidir. 
Tablo 3.4. Meteoroloji istasyonlarının isimleri data periyotlarl ve yükseklikleri (Güventürk, 2013)

\begin{tabular}{ccccccccc}
\hline Numarası & İstasyon & $\begin{array}{c}\text { Data } \\
\text { Periyodu }\end{array}$ & $\begin{array}{c}\text { Yükseklik } \\
(\mathbf{m})\end{array}$ & & Numarası & İstasyon & $\begin{array}{c}\text { Data } \\
\text { Periyodu }\end{array}$ & $\begin{array}{c}\text { Yükseklik } \\
(\mathbf{m})\end{array}$ \\
\hline 17199 & MALATYA & $1970-2010$ & 947 & & 17094 & ERZINCAN & $1970-2010$ & 1218 \\
17203 & BİNGÖL & $1970-2010$ & 1177 & & 17848 & BİTLİ & $1970-2010$ & 1573 \\
17165 & TUNCELI & $1970-2010$ & 981 & & 17285 & HAKKARI & $1970-2010$ & 1727 \\
17204 & MUŞ & $1970-2010$ & 1322 & & 17630 & ARDAHAN & $1970-2010$ & 1829 \\
17099 & AĞRI & $1970-2010$ & 1632 & & 17045 & ARTVIN & $1970-2010$ & 628 \\
\hline
\end{tabular}

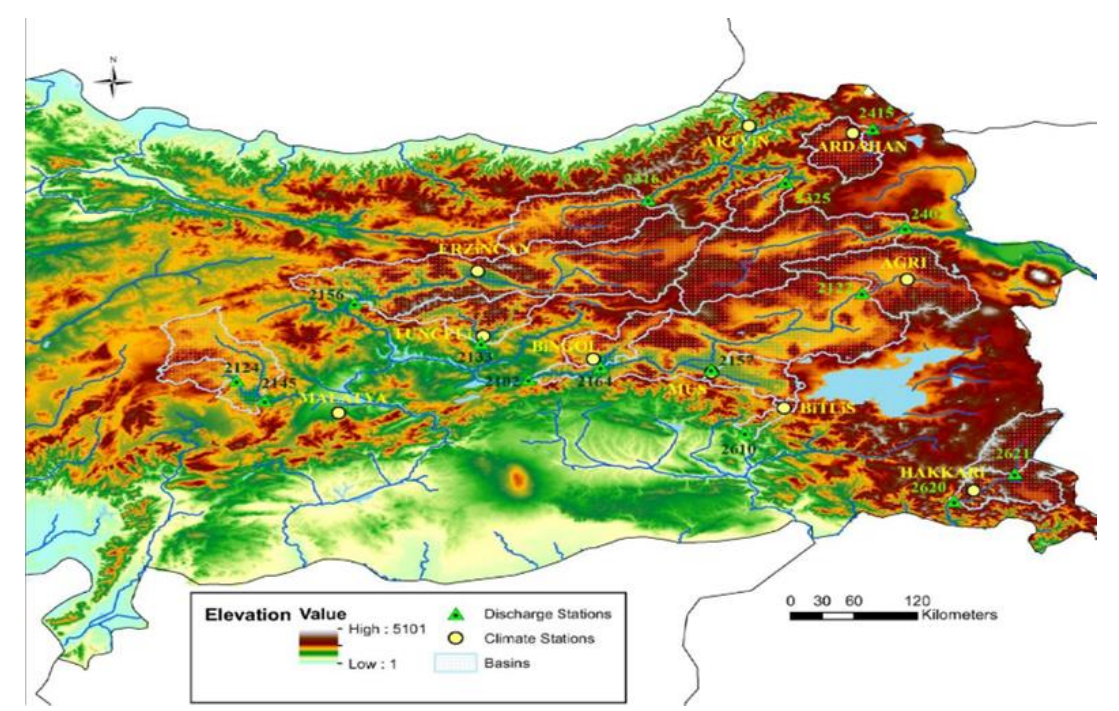

Şekil 3.5. Trend analizi yapılan akım gözlem ve meteoroloji istasyonları (Güventürk, 2013)

Tablo 3.5. Seçilen istasyonlarda 1970-2010 yılları için sıcaklık değişimleri (Güventürk, 2013)

\begin{tabular}{|c|c|c|c|c|c|}
\hline ISTASYON & \begin{tabular}{|l} 
MAKSIMUM \\
SICAKLIK \\
$\left({ }^{\circ} \mathrm{C}\right)$
\end{tabular} & $\begin{array}{l}\text { MINIIMUM } \\
\text { SICAKLIK } \\
\left({ }^{\circ} \mathrm{C}\right)\end{array}$ & $\begin{array}{c}\text { ORTALAMA } \\
\text { SICAKLIK } \\
\left({ }^{\circ} \mathbf{C}\right)\end{array}$ & $\begin{array}{l}\text { KASIM - ŞUBAT } \\
\text { ORTALAMA } \\
\text { SICAKLIK }\left({ }^{\circ} \mathrm{C}\right)\end{array}$ & $\begin{array}{l}\text { MART - HAZIRAN } \\
\text { ORTALAMA } \\
\text { SICAKLIK }\left({ }^{\circ} \mathrm{C}\right)\end{array}$ \\
\hline MALATYA & +2.0 & +1.2 & +1.6 & +1.6 & +1.6 \\
\hline BINGOL & +0.5 & 0.0 & +0.1 & +0.4 & +0.6 \\
\hline TUNCELI & +2.0 & +1.0 & +1.0 & +1.6 & +1.2 \\
\hline MUŞ & +1.5 & +2.5 & +2.0 & +2.3 & +2.8 \\
\hline AGRI & +2.0 & +2.4 & +1.9 & +2.7 & +2.2 \\
\hline ERZINCAN & +1.5 & +2.5 & +1.9 & +2.2 & +1.6 \\
\hline BITLIS & +1.5 & +0.6 & +0.8 & +1.1 & +1.4 \\
\hline HAKKARI & +0.5 & +0.9 & +1.3 & +1.7 & +1.4 \\
\hline ARDAHAN & +1.2 & +2.2 & +1.4 & +2.3 & +1.5 \\
\hline ARTVIN & +1.0 & +1.2 & +1.0 & +1.0 & +0.3 \\
\hline ORTALAMA & +1.37 & +1.45 & +1.30 & +1.69 & +1.46 \\
\hline
\end{tabular}

Tablo 3.6. 1970-2010 Yılları erime ve birikme sezonları için meteoroloji istasyonlarındaki yağış değişimleri (Güventürk A. 2013)

\begin{tabular}{|c|c|c|c|c|c|}
\hline \multirow[t]{2}{*}{ İSTASYON } & \multicolumn{2}{|c|}{$\begin{array}{c}\text { TOPLAM YAĞIŞTAKİ } \\
\text { DEĞIŞSIM (KASIM-ŞUBAT) }\end{array}$} & \multicolumn{2}{|c|}{$\begin{array}{c}\text { TOPLAM YAĞISSTAKİ } \\
\text { DEĞİșiM (MART-HAZİRAN) }\end{array}$} & \multirow{2}{*}{\begin{tabular}{|c}
$\begin{array}{c}\text { YILLIK YAĞISSTAKİ } \\
\text { DEĞIŞ̧iM }\end{array}$ \\
YÜZDE (\%)
\end{tabular}} \\
\hline & (mm) & YÜZDE (\%) & $(\mathrm{mm})$ & YÜZDE (\%) & \\
\hline MALATYA & +11.1 & 7.3 & -110.9 & -46.3 & -18.24 \\
\hline BINGOL & +76.0 & 15.6 & -58.5 & -14.7 & 6.9 \\
\hline TUNCELI & +82.6 & 20.6 & -17.8 & -5.7 & 13.0 \\
\hline MUȘ & $+73, .8$ & 21.8 & -17.5 & -5.3 & 10.8 \\
\hline AGRI & -60.3 & -28.2 & +1.7 & 0.7 & -5.1 \\
\hline ERZINCAN & +30.3 & 24.4 & +1.0 & 0.6 & 10.9 \\
\hline BITLIS & -47.5 & -7.4 & -7.2 & -1.5 & -3.1 \\
\hline HAKKARI & +49.6 & 13.5 & -84.5 & -26.8 & 0.05 \\
\hline ARDAHAN & +58.9 & 63.3 & +99.5 & 43.4 & 45.5 \\
\hline ARTVIN & +40.3 & 11.8 & +9.1 & 4.1 & 15.1 \\
\hline ORTALAMA & +31.48 & 14,3 & -18.5 & -5.2 & 7.5 \\
\hline
\end{tabular}




\section{ARAŞTIRMA BULGULARI ve TARTIŞMA}

\subsection{Kar Erimesi ile İlgili Analiz Sonuçları}

Meteoroloji istasyonlarının içinde bulundukları poligon alanlarına ait açıklamalar ile bu alanlar için SNOW alt programında kullanılmak üzere 2009-2011 yıllarındaki 3 yıllık kar gözlemleri kullanılarak kalibre edilen girdi değerleri, HSPF programında kullanılan İngiliz birim sisteminde, ayrıca metrik sistem karşılıkları da verilerek Tablo 4.1'de sunulmuştur.

Tablo 4.1. Meteoroloji istasyonlarının içinde bulunduğu poligonlar ve parametreleri

\begin{tabular}{|c|c|c|c|c|c|c|c|c|c|}
\hline 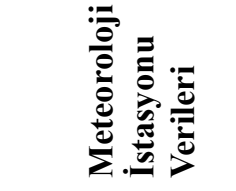 & 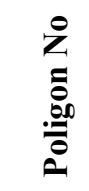 & 昰言 & 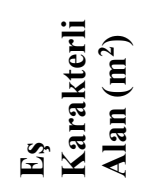 & 岁焉音 & 氛 & 氛 & 武 & $\begin{array}{l}5 \\
0 \\
0 \\
\vdots \\
0\end{array}$ & 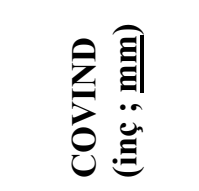 \\
\hline KÖŞK & 305 & Kuru.Tar. & 835601 & 40 & 6826,37 & $\underline{2080,68}$ & 0,43 & 1 & $2 ; \underline{50,8}$ \\
\hline GÜNGÖRMEZ & 120 & Değ. Alanı & 3522320 & 40 & 8256,79 & $\underline{2516,67}$ & 0,60 & 1 & $4 ; \underline{101,6}$ \\
\hline RADAR & 404 & Değ.Alanı & 2924080 & 40 & 9474,67 & $\underline{2887,88}$ & 0,72 & 1 & $4 ; \underline{101,6}$ \\
\hline 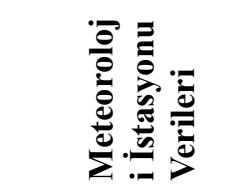 & 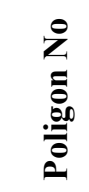 & 忒 & 苞 & 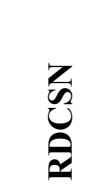 & 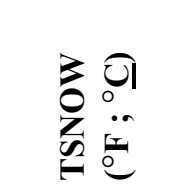 & $\sum_{\substack{1 \\
0}}^{0}$ & ن & 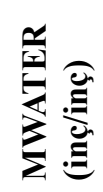 & 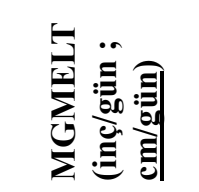 \\
\hline KÖŞK & 305 & Kuru.Tar. & 9,90 & 0,14 & $36 ; 2,22$ & 0,05 & 0,5 & 0,2 & 0,$02 ; \underline{0,0508}$ \\
\hline GÜNGÖRMEZ & 120 & Değ. Alanı & 24,10 & 0,16 & 31,$6 ;-0,22$ & 0,05 & 1,7 & 0,2 & 0,$02 ; \underline{0,0508}$ \\
\hline RADAR & 404 & Değ. Alanı & 12,06 & 0,16 & $40 ; \underline{4,44}$ & 0,05 & 2,0 & 0,2 & 0,$02 ; \underline{0,0508}$ \\
\hline
\end{tabular}

Şekil 4.1., Şekil 4.3 ve Şekil 4.5.'de sırasıyla Radar, Güngörmez ve Köşk istasyonlarını karakterize eden arazi parçalarına ait gözlenmiş ve simüle edilmiş sonuçlar verilmiştir. Sonuçlarda kullanılan kısaltmalar ve açıklamaları Tablo 4.2'de sunulmuştur (yağış ve akışa ait parametreler de modelde saatlik ölçekte simüle edilmiş olup çıktıların anlamlandırılabilmesi için günlük ölçekte gösterilmiştir).

Tablo 4.2. Şekil 4.1-6'da kullanılan kisaltmalar

\begin{tabular}{|c|c|c|}
\hline KISALTMA & AÇIKLAMA & TÜRÜ \\
\hline PRAIN & Kar kütlesi üzerine yağan yağmur yüks. (mm/gün) & Simüle edilmiş \\
\hline RAINF & Yağmur şeklindeki yağış yüksekliği (mm/gün) & Simüle edilmiş \\
\hline PREC & Toplam yağış yüksekliği (mm/gün) & Gözlenmiş \\
\hline WYIELD & $\begin{array}{l}\text { Kar kütlesinden dışarı salınan su miktarı (mm/gün), Sağ eksende } \\
\text { gösterilmiştir. }\end{array}$ & Simüle edilmiş \\
\hline PERO & $\begin{array}{l}\text { Geçirimli arazi parçasından çıkan toplam akış yüksekliği (mm/gün) } \\
\text {, Sağ eksende gösterilmiştir. }\end{array}$ & Simüle edilmiş \\
\hline SURO & Yüzeysel akış yüksekliği (mm/gün), Sağ eksende gösterilmiştir. & Simüle edilmiş \\
\hline SNWD & Kar kütlesinin yüksekliği (mm) & Gözlenmiş \\
\hline PDEPTH & Kar kütlesinin yüksekliği (mm) & Simüle edilmiş \\
\hline SWE & Kar su eşdeğeri (mm) & Gözlenmiş \\
\hline PACK & Kar su eşdeğeri (mm) & Simüle edilmiş \\
\hline PACKW & Kar kütlesindeki serbest su içeriği (mm) & Simüle edilmiş \\
\hline PACKF & Donmuş kütle içeriği (mm) & Simüle edilmiş \\
\hline PACKI & Buzlanmış kütle içeriği (mm) & Simüle edilmiş \\
\hline
\end{tabular}

Meteoroloji istasyonlarından alınan ham veriler incelendiği zaman Güngörmez ve Köşk istasyonlarına ait gözlenmiş SWE (kar su eşdeğeri) değerlerinin kar dönemi başında ve sonunda dönem dönem negatife düştüğü veya erime dönemi sonunda pozitifte kaldığ1 gözlenmiştir. Ölçüm aletinden kaynaklanan bu hatanın giderilmesi için, artışın başladığı veya bittiği noktanın 0'a kalibre edilmesi amacıyla kar dönemi boyunca veri serisi dikey eksende sapma miktarınca yukarı veya aşağı kaydırılmıştır. Köşk istasyonunda kar yüksekliğini ölçen ultrasonik sensördeki nemden kaynaklanan ölçüm hataları neticesinde tutarlı kar yüksekliği ölçümleri alınamamasına rağmen, istasyonda bağımsız olarak ölçülen SWE değerleri ile arazi çalışmalarından kar tüpü ile elde edilen SWE verileri karşılaştırılarak araziye uygun bir kar yüksekliği simülasyonu gerçekleştirilmiştir. Kar yüksekliği ve kar su eşdeğeri benzetimlerinde kar yastıklarının zemin kotundan bir miktar yukarıda (yaklaşık $30 \mathrm{~cm}$ ) kurulmasından dolayı, özellikle erime periyodunda düşük değerlerde ölçülen ve simüle edilen veriler arasında tam bir uyumun olması beklenilemez. 
Meteoroloji istasyonlarında ölçülen ve 1 saatlik zaman periyoduna göre simüle edilen kar su eşdeğerleri ve kar yükseklikleri değerlendirildiği zaman çok iyi bir korelasyonun sağlandığı görülmektedir (Şekil 4.1., Şekil 4.3 ve Şekil 4.5.). Kalibrasyonlarda farklı konumlarda kullanılan değişken kar parametreleri genelde yükseklik farkından kaynaklanmaktadır. Ancak, bazı parametreler havzanın karakteristiği ile de ilgilidir. Örneğin, SHADE parametresi göz önüne alındığında yükseklikle orantılı olarak SHADE değerinin arttığı gözlemlenmiştir. Bu parametrenin artması sonucu, kar yüzeyinin gelen kısa dalga radyasyonunu yansıtması artacak ve kütleye tesir eden net kısa dalga radyasyon miktarı azalacaktır. Normal iklim şartlarında kurulan bir modelde bu fiziksel davranış ALBEDO değişkeni ile değerlendirilmektedir. İterasyonlarla yürütülen HSPF gibi birçok modelin kar hidrolojisi simülasyonu hesaplarında arazide gözlenmiş albedo değerleri direk modele girdi olarak konulamamaktadır. Bunun yerine, kar yağışına bağlı olarak artıp azalan bir indekse bağlı olarak albedo zaman serileri diğer hidrolojik parametreler ile eşzamanlı olarak üretilerek modellerde kullanılmaktadır. Kar yağışına bağlı olarak HSPF benzetimlerinde üretilen ALBEDO serilerinin minimum ve maksimum aralıkları yaz ayları için 0,45-0,80 iken, kış ayları için 0,60-0,85 değerleri arasında kalmaktadır. Fakat, Kırkgöze havzası gibi yüksek dağlık alanlarda kurulan istasyonlardan alınan ölçümlerde albedo değerlerinin 0,98 'e varan değerler alabildiği ve uzunca bir müddet $0,90-0,98$ aralığında bu değerin dalgalandığı gözlenmiştir. HSPF modelinde güneşten gelen kısa dalga radyasyon Denklem 2.14'de belirtildiği üzere;

SHORT $=$ SOLRAD $*(1,0-A L B E D O) *(1,0-$ SHADE $)$

bağıntısından hesaplanmaktadır. Bu nedenden ötürü ALBEDO parametresinin modeli kalibre etme kapasitesinin yetersiz olduğu şartlarda, SHADE parametresi arazi şartlarını modelde daha iyi yansıtmak amacıyla yardımcı bir fonksiyon olarak kullanılabilir. Sirasıyla 2080,68 m, 2516,67 m ve 2887,88 m yüksekliklerinde kurulan Köşk, Güngörmez ve Radar istasyonları için SHADE parametresi 0,43, 0,6 ve 0,72 olarak kullanıldığında karın olması gerektiği gibi uzun bir dönem arazi üzerinde kalması sağlanmıştır.

Bir başka bakış açısıyla; Radar istasyonundaki kar yağışı, Güngörmez ve Köşk istasyonuna göre daha fazla ise, yüksek rakımlar için modelde üretilen ALBEDO değerlerinin de yağışa paralel olarak diğerlerinden daha fazla olması gerekmektedir. SOLRAD değerlerini modellerken eksik olarak modellenen ALBEDO değerlerinin kademeli olarak daha yüksek bir aralıkta salınımını sağlamak amacıyla, ALBEDO değerinin sabit bir SHADE katsayısı ile çarpılması ile fiziksel olarak daha anlamlı sonuçların elde edilmesi beklenir. Fakat, modelde üretilen maksimum albedo değerleri tüm istasyonlarda sabit bir değer (örn. 0,85) almaktadır. Gerçekte ise, dağlık alanlarda yükseklere çıkıldıkça kar daha temiz olduğundan daha yüksek albedo değerleri alması ve güneş radyasyonundan daha az etkilenmesi beklenir. Bu durumun, dağlı alanların düşük kotlarındaki erken erime neticesinde açığa çıkan yüzeysel kirliliğin rüzgârlarla kar kaplı alanların üzerine taşınması ile yüzey kirliliğinin alt kotlardan üst kotlara doğru eksponansiyel olarak azalmasının bir sonucu olduğu da düşünülebilir. Bu nedenle kurulan modelde SHADE parametresinin üst kotlara doğru çıktıkça artan değerler alması, fiziksel olarak anlamlıdır. Sonuçta dağlık alanlarda yüksek rakımlarda kısa dalga radyasyonun erimede daha az etkili olduğu sonucu ortaya çıkar.

SHADE parametresinin artması, kısa dalga boylu radyasyonun erime sürecindeki etkisini azaltırken diğer taraftan Denklem 2.15 ve Denklem 2.16 gereğince sıcaklığa bağlı olarak uzun dalga radyasyonunu arttırmaktadır. Daha yaygın bir şekilde ölçülen kısa dalga radyasyona kıyasla, uzun dalga radyasyonu (LONG) kar kütlesinin ve çevresinin yayma özelliklerinin teorik değerlendirmesinden tahmin edilir. Stefan'ın Siyah Cisim Yasası esas alınarak ortaya konan kuramsal temeller ile gerçekleştirilen LONG simülasyonlarında SHADE parametresi 1'e yaklaştıkça arazide uzun dalga radyasyonun etkisi artmaktadır. Bu durumu bulut örtüsü etkisi ile açıklayacak olursak, dağlık alanlarda zirveye doğru çıkıldıkça arazi parçasından taranacak gökyüzü alanı artacaktır. Aynı şekilde, üst kotlarda bulunan bir arazi parçasının görebileceği alansal kara parçası da artacaktır. Sonuçta, uzun dalga radyasyonunun erimeye olan etkisi yüksek rakımlarda düşük rakımlara kıyasla daha fazla olacaktır. Bu nedenle üst kotlara doğru çıktıkça SHADE parametresinin artan değerler alması kurulan modelde fiziksel olarak anlamlıdır.

CCFACT parametresi Köşk, Güngörmez ve Radar istasyonları için sırasıyla 0,5, 1,7 ve 2,0 olarak kalibre edilmiştir. Bu parametrenin yüksek rakımlara doğru çıkıldıkça artan değerler alması konveksiyon (iletim) ve kondansasyon (yoğunlaşma) yoluyla kar kütlesinde meydana gelen 1sı değişiminin, üst kotlarda düşük kotlara göre daha etkili olduğunu ortaya koymaktadır. Sonuç olarak CCFACT parametresi hava sıcaklığı ve rüzgâr hızının bir fonksiyonu olduğundan dolayı, hava sıcaklığının erimeye olan katkısı yüksek rakımlarda düşük rakımlara göre daha etkilidir (Şengül, 2011).

Küresel iklim değişikliği etkilerinin bölgedeki yağış ve sıcaklık değişkenlerine olan tesirleri yapılan çalışmalar incelendiği zaman 1970-2010 yılları arasındaki 40 yıllık bir zaman zarfında belli oranlarda ortalama bir trend göstermiştir. HSPF modeli kullanılarak bölgenin kar erimesi ve birikmesine etki eden fiziksel davranış modellenmiş olup bu trendlerin modeli itere eden meteorolojik zaman serilerine uygulanması ile bundan sonraki 40 yıllık süreç sonunda bölgedeki kar kütlesinin davranışı simüle edilmiştir (Şekil 4.2, Şekil 4.4, Şekil 4.6). İklim senaryosu modellenirken halihazırdaki yağı̧s ve sıcaklık ile ilgili meteorolojik zaman serilerinine (Hava Sıcaklığı, Yağı̧̧ ve Çiğ noktası) yapılan çalışmalar sonucunda erime ve birikme dönemlerinde farklı trendler uygulanmış olup modelde girdi olarak kullanılan diğer meteorolojik şartların değişmediği kabulü yapılmıştır. Hava sıcaklığı Çiğ noktası hesaplamaları haricinde evapotranspirasyon zaman serileri üzerinde de etkili olmakla beraber kar kütlesinden meydana gelen süblimleşme modelde çiğ noktası değeri (DEWP) üzerinden hesaplanmaktadır. Evapotranspirasyon zaman serileri ise daha çok kar örtüsünün yüzeyden kalkması sonucu etkin olmaktadır. Bu nedenle kar kütlesi ile ilgili hesaplamalarda etkin değildir. Tablo 3.5 ve 3.6'dan elde edilen bulgular neticesinde 40 yıllık bir zaman periyodu sonrasında Doğu Anadoluda'ki dağlık alanların ortalama bir davranışını simüle edebilmek maksadıyla ortlama değerler üzerinden trend uygulanması uygun görülmüştür. Buna göre hali hazırdaki sıcaklık zaman serilerinin kar birikme dönemlerine denk gelen Kasım-Şubat aylarındaki değerleri 1.69 Santigrad derece; kar erime dönemlerine denk gelen Mart-Haziran aylarındaki değerleri 1.46 Santigrad derece ve son olarak da geriye kalan aylardaki ortlama sıcaklık değerleri 1.30 Santigrad derece arttırılmıştır. Çalışmada özellikle kar kütlesi üzerindeki davranış modellendiği için yağış serilerinde ise Kasım-Şubat aylarında yağış serileri \%14.3 arttılmış; Mart-Haziran aylarındaki değerlerde ise \% 5.2 derecesinde azaltım yoluna gidilip kar örtüsünün gözlenmediği geri kalan aylardaki yağı̧̧ serilerinde herhangi bir trend uygulanmaya ihtiyaç duyulmamıştır. 

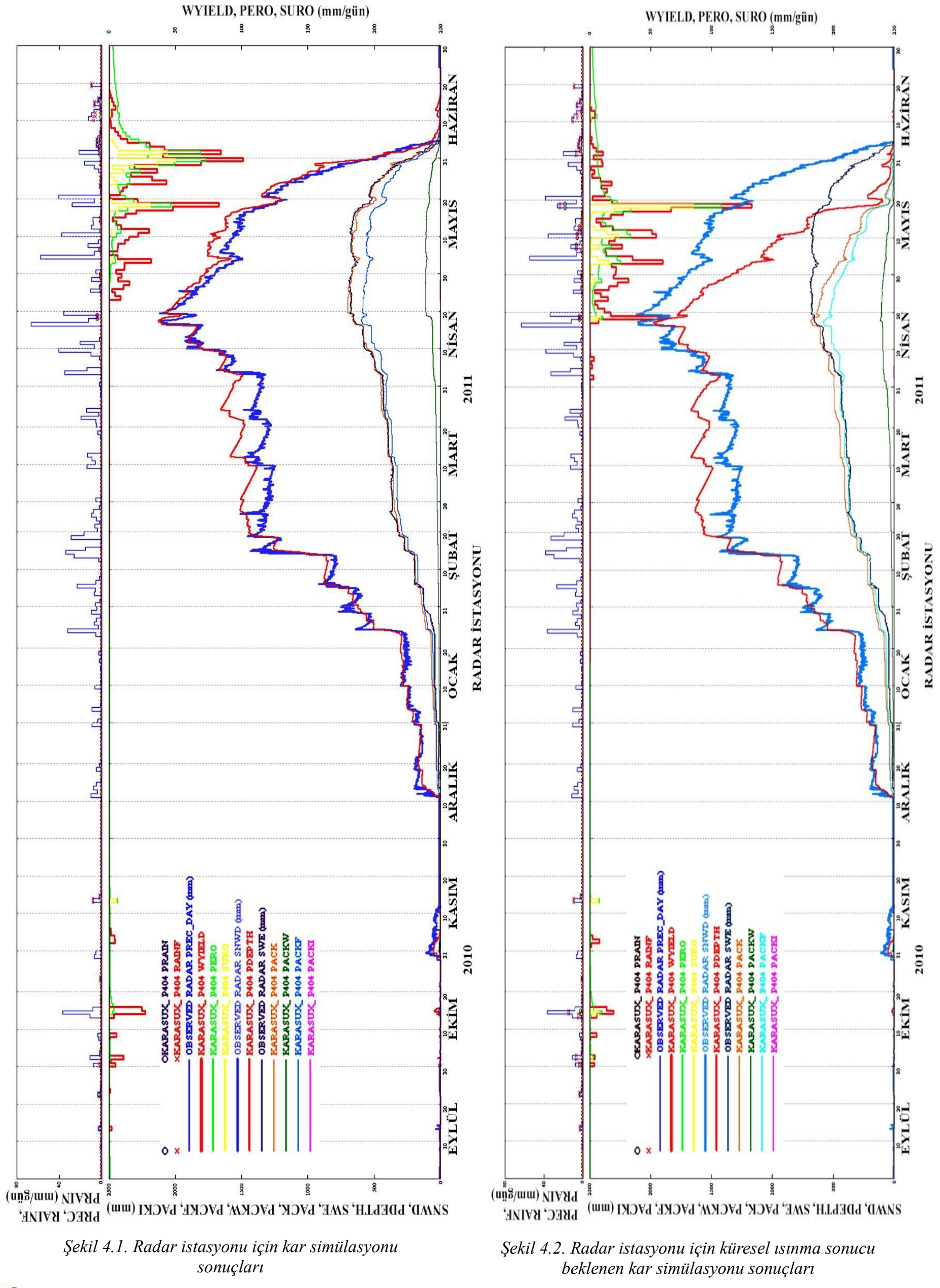


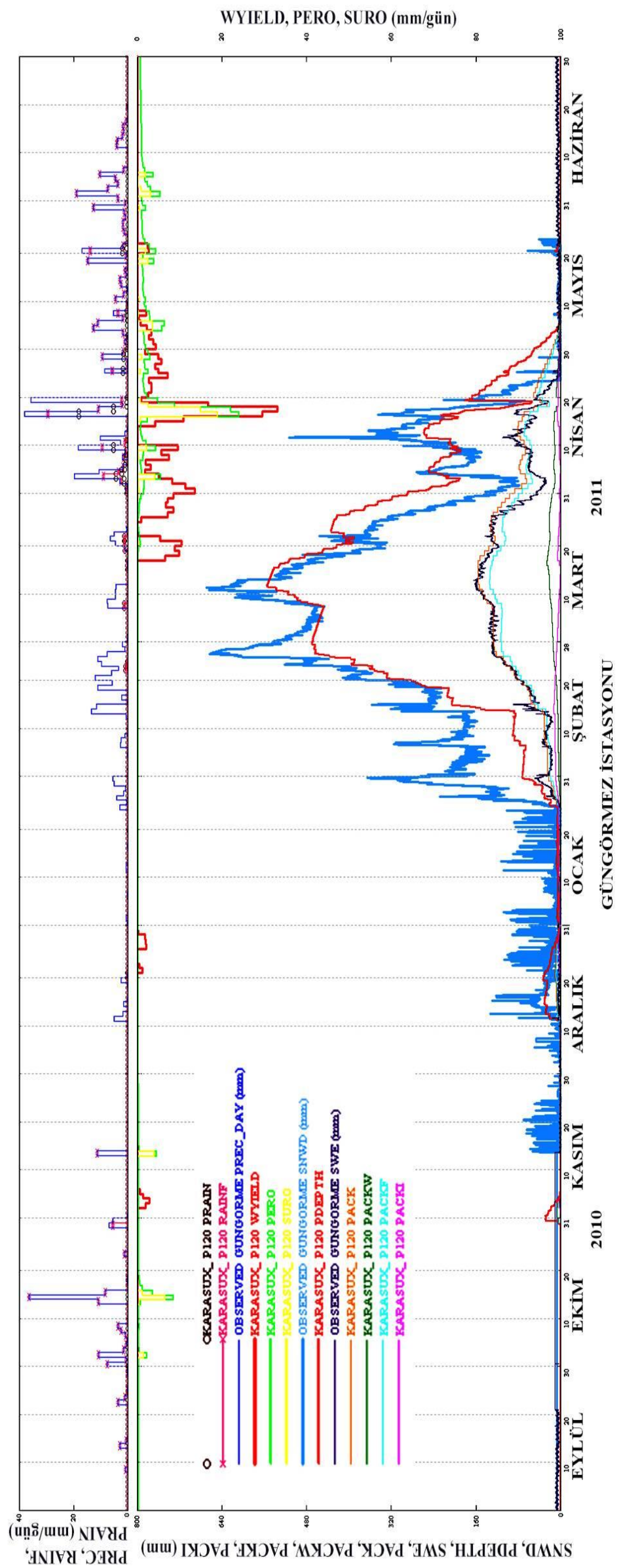

Şekil 4.3. Güngörmez istasyonu için kar simülasyonu sonuçları
WYIELD, PERO, SURO (mm/gïn)

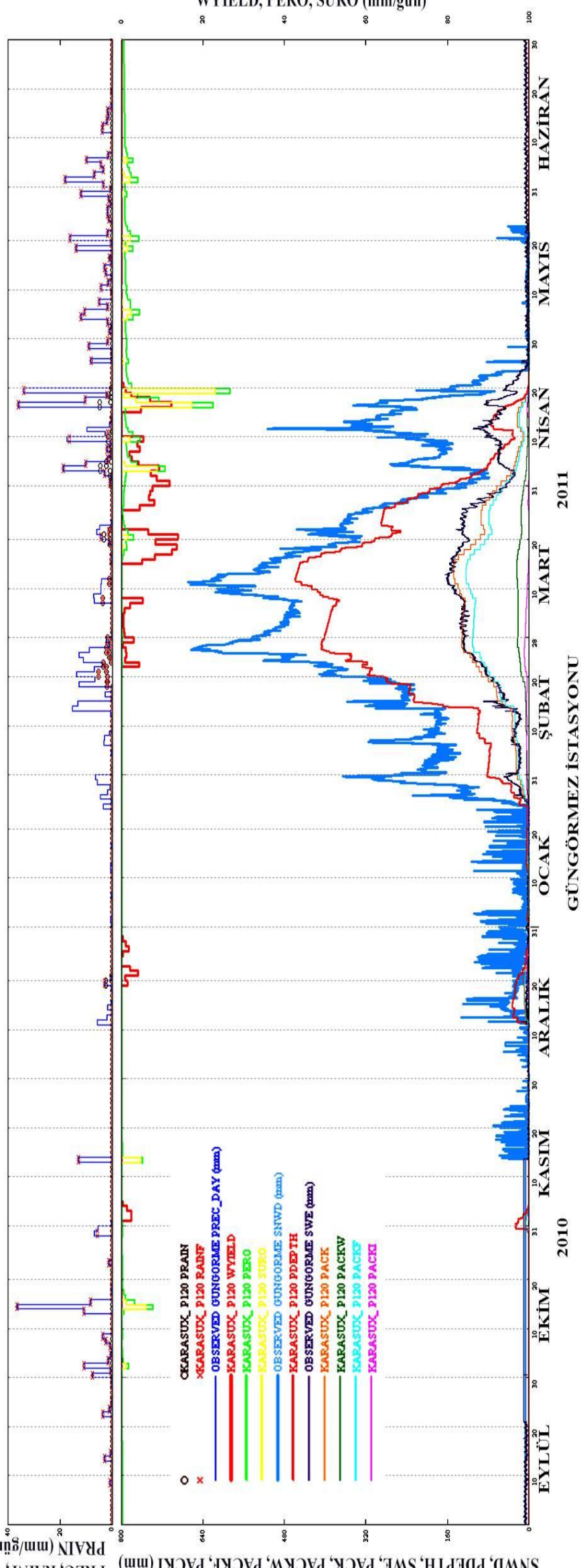

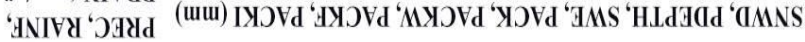

Şekil 4.4. Güngörmez istasyonu için küresel ısınma sonucu beklenen kar simülasyonu sonuçları 


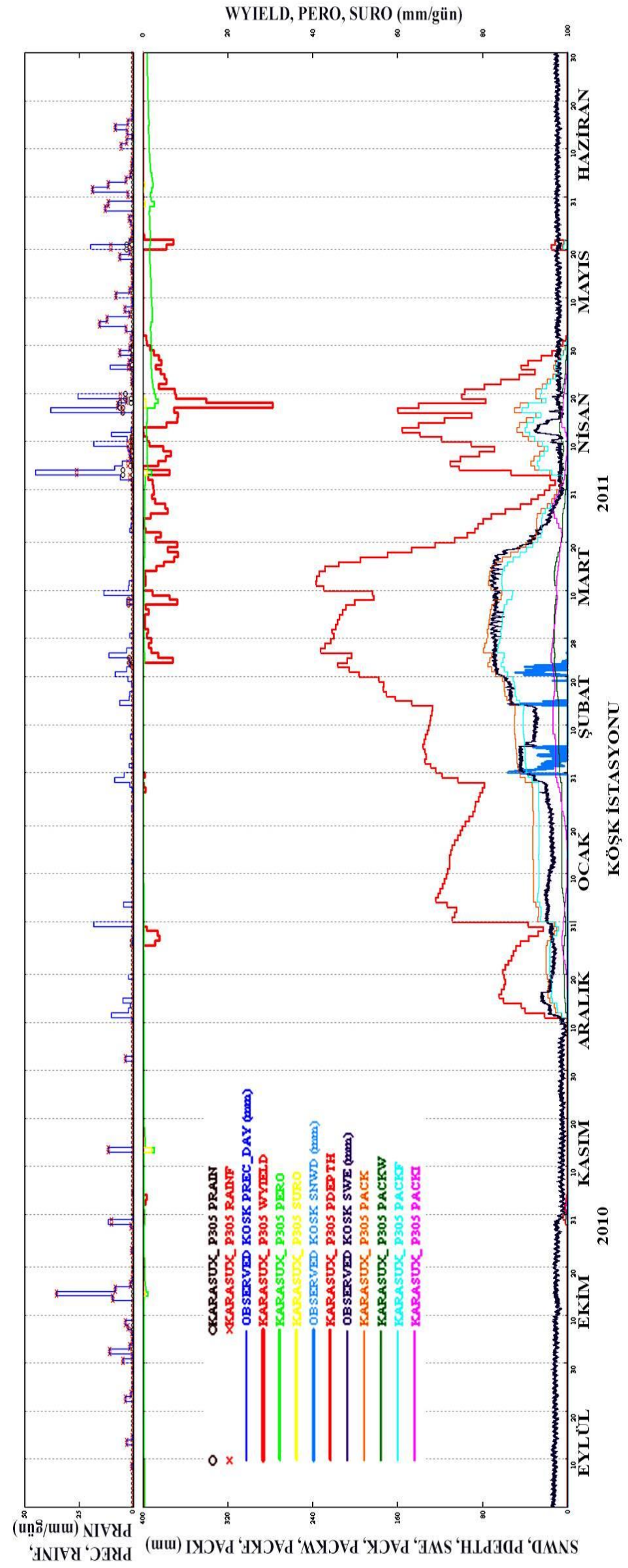

Şekil 4.5. Köşk istasyonu için kar simülasyonu sonuçları

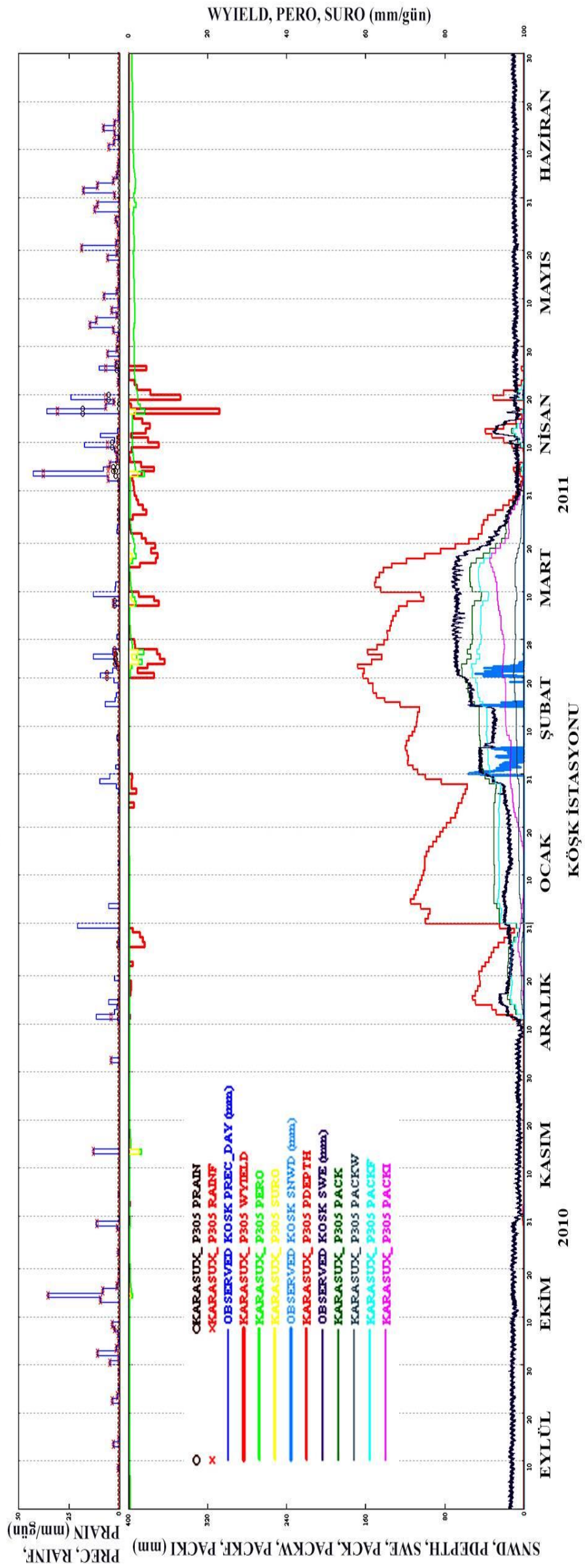

Şekil 4.6. Köşk istasyonu için küresel ısınma sonucu beklenen kar simülasyonu sonuçları 


\section{SONUÇ ve ÖNERILER}

$\mathrm{Bu}$ çalışmada, temelde bir coğrafi bilgi sistemi olup çok işlevli havza analizi araçlarını barındıran BASINS yazılımı farklı CBS algoritmalarıyla desteklenerek veri toplama, veri hazırlama ve havza karakterizasyonu ön işlemleri gerçekleştirilmiştir. BASINS ile elde edilen çıktılar, hidrolojik simülasyon programı olan HSPF uygulaması için girdi olarak kullanılmış ve havza modeli oluşturulmuştur. Yıllık toplam akımların önemli bir bölümünün (\%70-80) kar erimelerinden oluştuğu, Kırkgöze (Çipak) havzası kar kütlesi simülasyonları gerçekleştirilmiştir.

BASINS içinde bulunan MapWindow arayüzü ile birlikte, diğer bir CBS yazılımı olan ARCGIS programının alt modüllerinin sağladığı ileri CBS olanakları da kullanılarak topolojik ve iklimsel değişkenler gözetilerek meteorolojik ve hidrolojik açıdan eş karakterizasyona sahip arazi sınırları belirlenmiştir. Meteoroloji istasyonlarının bulunduğu her bir poligonal alan kendi ortam değişkenlerinin stabil olduğu bir sınıra indirgenmiştir. Böylelikle BASINS çatısı altında kullanılacak olan HSPF uygulaması için hidrolojik model tabanı oluşturulmuştur.

HSPF model programı kullanılarak her biri farklı eş karakteristikli alan içinde bulunan istasyonlardan ölçülen ve işlenen veriler gözlenmiş kar su eşdeğeri ve kar yüksekliği değerlerini simüle edecek şekilde kalibre edilerek modellenmiştir. Öncelikli olarak her bir istasyondaki ham meteorolojik zaman serileri (hava sıcaklığı, hava nemi, hava basıncı, yağış, rüzgâr hızı ve güneş radyasyonu) 1'er saatlik ölçekte işlenerek modelde kullanılacak olan gerekli zaman serilerine (hava sıcaklığı, çiğ noktası sıcaklığı, yağış ve bulutluluk, rüzgâr hızı, potansiyel evapotranspirasyon ve güneş radyasyonu) dönüştürülmüştür. Müteakiben meteoroloji istasyonlarının kurulu olduğu arazi parçalarına ait HSPF modelindeki kar birikmesi ve erimesi süreci ile ilgili parametreler gözlenmiş kar su eşdeğeri ve kar yüksekliklerini verecek şekilde Tablo 4.1'de gösterildiği gibi tayin edilmiştir. İleride yapılacak olan çalışmalarda havza içinde veya bölgede farklı noktalardan elde edilen bu noktasal parametrelerin zamansal ve mekânsal dağılımı yapılarak herhangi başka bir nokta veya alan için kar derinliği, kar su eşdeğeri, kar kütlesinin buz ve serbest su içeriği, kar kütlesi üzerine düşen yağmur yüksekliği ve kar kütlesinden sızan su miktarı belirlenebilir.

Alansal karakterizasyonun değişiklik göstermesine kavramsal bir örnek olarak şu sonuçlar verilebilir.

1) Dağlık alanlar için SHADE parametresinin çıplak arazide üst kotlara doğru çıkıldıkça artan değerler alması, yüksek rakımlara doğru çıkıldıkça kısa dalga radyasyonun kar erimesi üzerine olan etkisinin azaldığını ve uzun dalga radyasyonunun kar erimesi üzerine etkisinin arttığını göstermektedir.

2) Hava sıcaklığı ve rüzgâr hızının bir fonksiyonu olan CCFACT parametresinin üst kotlara doğru çıkıldıkça artan değerler alması, yüksek rakımlarda hava sıcaklığının erimeye olan katkısının düşük rakımlara göre daha etkili olduğunu belirtmektedir.

Değişimin ne derecede gerçekleştiği ise model parametrelerinin aldığı değerlerin (Tablo 4.1) Bölüm 2.2'de verilen fiziksel davranış denklemlerinde incelenmesi veya GENSCN alt programından çıktı olarak sunulan nihai grafiklerin (Şekil 4.1-4.6) incelenmesi ile anlaşılır olmaktadır.

Şekil 4.1, Şekil 4.3 ve Şekil 4.5'de sırasıyla 2891 metre rakımında bulunan Radar istasyonu, 2454 metre rakımında bulunan Güngörmez istasyonu ve 2019 metre yüksekliğinde bulunan Köşk istasyonu içsel kar kütle davranışları ve bu kütlelerden çıkan suların zamansal ve akış yüksekliği olarak değerleri grafik olarak sunulmuştur. Bunlara ek olarak özellikle erime dönemi yağışlarının kar olarak mı yoksa yağmur formunda mı gerçekleştiği, yağmurun kar örtüsü üzerine yağdığı zaman kar kütlesinin ne şekilde davranış gösterdiğini de grafiklerden okumak mümkündür. Kırkgöze havzası üzerinde bulunan kar örtüsünün erime periyodu artan pikleri incelendiğinde karla karışık yağan yağmurun kar kütlesi içinden direk süzülmeyip kar yüksekliğini arttırdığı gözlenmiştir. Bu benzetim ancak MWATER parametresinin literatürce ekstrem bir değer olan 0.2 değerinde sağlanmış olup bölgedeki kar kütlesinin petek yapısının gün içindeki ısı değişiminin fazla olması neticesinde oluşan donma çözünme dinamikleri sonucunda kütle üstünde bulunan buzul tabakanın zamanla yeni yağan kar sonucunda tekrarlanarak katmanlaşmasına ve kütle içinden suyun serbest akışına izin vermemesi ile açıklanabilir. Ayrıca erime döneminde özellikle kar yüksekliğinin fazla olduğu yüksek rakımlarda yapılan arazi gezilerinde erimeye başlayarak olgunlaşan kar kütlesinin neredeyse yarım metreye yakın kısmının su kıvamında olduğu gözlenmiş, kar hediği takılmasına rağmen bazı yerlerde yürümenin neredeyse imkânsız hale geldiği tecrübe edilmiştir.

Erime döneminde istasyonların genelinde kar kütlesinin ani olarak düşüm gösterdiği kısımlarda ise kar kütlesinden salınan serbest suyun (WYIELD) pik değerler almış olduğu ve ani erimenin büyük ölçüde kar üzerine yağan yağmurun (PRAIN) bir sonucu olduğunu söyleyebiliriz. Şekil 4.2, Şekil 4.4 ve Şekil 4.6'da verilen iklim değişikliği trendleri altında 2050 yılı için modellenen öngörüler incelendiğinde ise erime dönemlerinde kar kütlesinden salınan su miktarında (WYIELD) ve yüzeysel akış yüksekliklerinde (SURO) 2011 özgün değerleri ile karşılaştırıldığında yüksek rakıma ve kuzey bakıya sahip Radar istasyonunda orantısal olarak yüksek miktarda gözlemlenen bir artış göze çarpmaktadır. WYIELD değerinin pik değeri 100 mm'den 140 mm'ye çıkarken, SURO ifadesi 50 mm değerinden $80 \mathrm{~mm}$ değerine kadar artış göstermiştir. Büyük miktarlarda su içeren, kar yüksekliğinin fazla olduğu ve erimenin geç bir zamanda gerçekleştiği kuzey bakılı Radar istasyonu konumundaki araziler için küresel 1sınma neticesinde öne çekilen erime periyodunda arazi üzerinde bulunan kar örtüsü üzerine, yağmur şeklinde gerçekleşen yağışın etkisi ile kütlede karın serbest su taşıma yüzdesi aşıldığı anda beklenen değerlerden oldukça fazla su salınımı ve yüzey akışı gerçekleşmektedir. Nitekim erime dönemi yağış ve sıcaklık trendlerine bakıldığı zaman sıcaklığın 1.46 Santigrad derece artış gösterdiği; yağışın ise Mart-Haziran boyunca \%5.2 azaldığ göz önünde tutuduğunda erime dönemi boyunca kar kaynaklı toplam akış hacminin azaldığ (SWE değerinin altında kalan alan) ancak akışın pik taşkın değerlerinin (WYIELD, SURO) oldukça yüksek değerler aldığı gözlenmektedir.

Güney bakıya sahip Güngörmez İstasyonunda WYIELD değeri 35 mm'den 10 mm değerine düşerken yüzey akımını temsil eden SURO değeri $20 \mathrm{~mm}$ den 22 mm'ye çıkarak yaklaşık aynı kalmıştır. Güngörmez istasyonundaki WYIELD değerinde gözlemlenen düşümün erimenin artan hava sıcaklığı ile öne çekilmesi sonucu kar örtüsü üzerine yağan yağmur etkisinin azalması ile açıklayabiliriz. 
Düşük rakımda bulunan ve kuzeybatı bakısına sahip Köşk istasyonu için ise kar erimesi kaynaklı pik debinin aynı şekilde $32 \mathrm{~mm}$ değerinden $25 \mathrm{~mm}$ değerine düştüğü ancak yüzey akımının pik değerlerinde herhangi bir değişim olmadığı göze çarpmaktadır.

Yüksek rakımlarda bulunan Radar ve Güngörmez istasyonunda kar birikme sürecinde Mart ayına kadar önemli değişiklik gözlenmez iken kar erime sürecinin Radar istasyonunda yaklaşı 15 gün, daha fazla solar radyasyona maruz kalan güney bakıya sahip Güngörmez istasyonunda ise 25 gün öne geldiği gözlenmiştir. Köşk istasyonu ise diğer istasyonlardan daha düşük bir rakımda bulunduğundan yüksek ortam sıcaklığı ve düşük kar birikmesine bağlı olarak Şubat ayında başlayan erime süreci 5 gün kadar erkene çekilmiş olup erime periyodunda ise 10 günlük bir geri çekilme söz konusudur.

Her ne kadar söz konusu istasyonlar Kırkgöze Havzası'nın hipsometrik ortalama yüksekliklerinde bulunsalar da havza geneli için akım gözlem istasyonlarında gelecekte gözlemlenebilecek reel yüzeysel akımların debi değerleri için gerek mevcut model parametrelerin havza alanı üzerinde bütün araziye dağıtıllığı ve su bütçesi hesaplarının kapsamlı olarak gerçekleştirildiği hidrolojik modellere gerekse IPCC raporlarından farklı seneryolar için elde edilebilecek global iklim değişikliği eğilimlerinin hidrolojik modeldeki tüm meteorolojik değişkenleri üzerindeki indirgenmiş değerleri kullanılarak elde edilecek tahminlerine ihtiyaç duyulmaktadır. Yine de dağlık Kırkgöze Havzası yüzeysel akımlarının büyük ölçekte üst kotlarda bulunan yüksek kar kütlelerinin erimesinden kaynaklandığı düşünüldüğünde bu çalışmadan elde edilen veriler ilerleyen dönemde bölgesel ölçekte taşkın debilerdeki önemli bir artı̧̧ı işaret etmektedir. Bu durum taşkın koruma yapılarının, yapıların ekonomik ömürleri boyunca etkili bir şekilde hizmet verebilmesi için küresel ısınma dinamiklerinin göz önünde tutularak hesaplanması ve gerekiyor ise mevcut yapıların da tekrar boyutlandırılması gerektiği sonucunu doğurmaktadır.

Güngörmez istasyonu verilerinin analizinde ise erken dönem bahar yağışlarının yüksek kotlarda beklendiği üzere artık kar olarak değil, 2454 metre rakımlarından başlayarak aşağıya doğru yağmur şeklinde yağacağı sonucu çıkmakta olup bu durum yine yağışın zamanda ertelenmeden direk akışa geçeceğini göstermektedir. Köşk istasyonu verileri incelendiğinde ise analizler sonucu artık 2019 metre rakımlarında 2050 yılı kar kotunun gittikçe yükseldiği yani karın artık daha yüksek kotlarda birikmeye başlayacağı ve düşük rakımlarda kar kütlesine eskiye nazaran oldukça az miktarlarda kar gözleneceği sonucu çıkmaktadır ki bu durum özellikle kış sporlarının yapıldığı Doğu Anadolu'da mevcut bulunan farklı disiplinlerdeki kar sporları ile ilgili tesislerin geleceğe yönelik projeksiyonlarının yapılması hususunda önem arz etmektedir.

Sonuç olarak, bu çalışmada HSPF modeli ile çalışma havzası için enerji bütçesi metedolojisi kullanılarak yüksek korelasyonlu kar kütlesi benzetimlerinin simüle edilebileceği gösterilmiş olup, kar örtüsü üzerine yağan yağmurun ve erken erime sonucu çıplak arazi üzerine yağarak direk akışa geçen yağmurun gözlenen debiler üzerinde önemli etkilerinin olduğu sonucuna varılmıştır. Elde edilen model parametreleri başka dağlık havzalarda gerçekleştirilecek olan hidrolojik modeller ve iklim modelleri için de kaynak teşkil etmektedir.

\section{TEŞEKKÜR}

Bu çalışmada kullanılan meteoroloji ve kar gözlem istasyonlarının kurulumunda önemli katkıları bulununan başta Prof. Dr. Reşat ACAR ve Dr. Öğr. Üyesi Serkan ŞENOCAK olmak üzere istasyonların halihazırda işletilmesi ve bakımlarında katkıları bulunan Arş.Gör. Okan Mert KATIPOĞLU ve Muhammet Nuri İSPİRLI'ye; ayrıca ilgili çalışma alanının yağış ve sıcaklık trendlerini belirleyerek literatüre kazandıran Prof. Dr. İsmail Yücel, Abdulkadir Güventürk ve çalışma arkadaşlarına da teşekkürlerimi sunarım.

Bu çalışma Atatürk Üniversitesi Bilimsel Araştırma Projeleri Koordinasyon Birimi (BAP) tarafından kabul edilen PRJ2016/5-2613 nolu temel araştırma projesi kapsamında desteklenmiştir. 


\section{Kaynakça}

Acar, R., Şenocak, S., \& Şengül, S. (2009). Snow hydrology studies in the mountainous eastern part of Turkey. Paper presented at the 2009 IEEE International Conference on Industrial Engineering and Engineering Management.

Acar, R., Şenocak, S., Şengül, S., Coşkun, T., \& Balık Şanlı, F. (2009). Erzurum Kırkgöze Havzasında Kar Erimesine Etki Eden Meteorolojik Ölçümlerin Üç Istasyonda Karşılaştırılması. Paper presented at the III. Ulusal Kar Kongresi.

Al-Abed, N. A., \& Whiteley, H. R. (2002). Calibration of the Hydrological Simulation Program Fortran (HSPF) model using automatic calibration and geographical information systems. Hydrological processes, 16(16), 3169-3188.

Anderson, E. A. (1968). Development and testing of snow pack energy balance equations. Water Resources Research, 4(1), 19-37.

Anderson, E. A., \& Crawford, N. H. (1964). The synthesis of continuous snowmelt runoff hydrographs on a digital computer, Department of Civil Engineering: Stanford University, Stanford, California, Technical Report.

Anonymous. (1956). Summary report of the snow investigations: North Pacific Division. US Army Corps Eng., Portland, Oreg. 437pp.

Anonymous. (1998). Engineering and Design: Runoff from Snowmelt (CECW-EH Engineer Manual 1110-2-1406). Retrieved from Washington, D.C.:

Anonymous. (2007). Better Assessment Science Integrating Point and Nonpoint Sources BASINS 4.0, User's Manual. EPA-823-C-07001, Washington, DC.

Arnell, N. W. (1999). Climate change and global water resources. Global environmental change, 9, S31-S49.

Bergman, M., Green, W., \& Donnangelo, L. (2002). Calibration of storm loads in the South Prong watershed, Florida, using basins/HSPF 1. JAWRA Journal of the American Water Resources Association, 38(5), 1423-1436.

Bicknell, B., Imhoff, J., Kittle Jr, J., Jobes, T., \& Donigian Jr, A. (2001). Hydrological Simulation Program-Fortran (HSPF). User's Manual for Release 12. US EPA National Exposure Research Laboratory, Athens, GA, in cooperation with US Geological Survey. Water Resources Division, Reston, VA.

Bicknell, B. R., Imhoff, J. C., Kittle Jr, J. L., Donigian Jr, A. S., \& Johanson, R. C. (1997). Hydrological simulation programFORTRAN user's manual for version 11. Environmental Protection Agency Report No. EPA/600/R-97/080. US Environmental Protection Agency, Athens, Ga.

Carrubba, L. (2000). HYDROLOGIC MODELING AT THE WATERSHED SCALE USING NPSM 1. JAWRA Journal of the American Water Resources Association, 36(6), 1237-1246.

Choi, W., \& Deal, B. M. (2008). Assessing hydrological impact of potential land use change through hydrological and land use change modeling for the Kishwaukee River basin (USA). Journal of Environmental Management, 88(4), 1119-1130.

Crawford, N. H. (1999). Snowmelt Calibration. Hydrologic Journal. Retrieved from www.hydrocomp.com

Donigian, A. S., \& Davis, H. H. (1978). User's Manual for Agricultural Runoff Management(ARM) Model. Available from the National Technical Information Service, Springfield VA 22161 as PB-286 366, Price codes: A 08 in paper copy, A 01 in microfiche. Report.

DSİ. (2009). Turkey Water Report. Retrieved from Republic of TURKEY:

El-Kaddah, D. N., \& Carey, A. E. (2004). Water quality modeling of the Cahaba River, Alabama. Environmental geology, 45(3), 323338.

Endreny, T. A., Somerlot, C., \& Hassett, J. M. (2003). Hydrograph sensitivity to estimates of map impervious cover: a WinHSPF BASINS case study. Hydrological processes, 17(5), 1019-1034.

Griessinger, N., Schirmer, M., Helbig, N., Winstral, A., Michel, A., \& Jonas, T. (2019). Implications of observation-enhanced energybalance snowmelt simulations for runoff modeling of Alpine catchments. Advances in Water Resources, 133, 103410. doi:https://doi.org/10.1016/j.advwatres.2019.103410

Güventürk, A. (2013). Impacts Of Climate Change on Water Resources on Eastern Mountainous Region Of Turkey. (Msc), Middle East Technical University, Ankara,Turkey.

Hayashi, S., Murakami, S., Watanabe, M., \& Bao-Hua, X. (2004). HSPF simulation of runoff and sediment loads in the Upper Changjiang River Basin, China. Journal of Environmental Engineering, 130(7), 801-815.

Im, S., Brannan, K. M., Mostaghimi, S., \& Cho, J. (2004). Simulating fecal coliform bacteria loading from an urbanizing watershed. Journal of Environmental Science and Health, Part A, 39(3), 663-679.

IPCC. (2007). Impacts, Adaptation, and Vulnerability (Eds. ML Parry, OF Canziani, JP Palutikof, PJ van der Linden, CE Hanson) (Vol. 4): Cambridge University Press, UK.

Rango, A., \& Martinec, J. (1995). REVISITING THE DEGREE-DAY METHOD FOR SNOWMELT COMPUTATIONS 1. JAWRA Journal of the American Water Resources Association, 31(4), 657-669.

Seaber, P., Kapinos, F., \& Knapp, G. (1987). Hydrologic Unit Maps. United States Geological Survey Water-Supply Paper 2294. US Geological Survey: Anchorage, AK, USA.

Sen, O., Unal, A., Bozkurt, D., \& Kindap, T. (2011). Temporal changes in the Euphrates and Tigris discharges and teleconnections. Environmental Research Letters, 6(2), 024012.

Şengül, S. (2011). Dă̆lık Havzalarda Hidrolojik Çevrime Etki Eden Parametrelerin Coğrafi Bilgi Sistemleri ve HSPF Model Programıla İncelenmesi ve Kırkgöze Havzası Örneği. (PhD), Atatürk Üniversitesi, Fen Bilimleri Enstitüsü, Erzurum, Türkiye.

Şenocak, S. (2011). Kar Erimesi Akış Modelinin (SRM), Coğrafi Bilgi Sistemleri ve Uzaktan Algılama Teknikleri de Kullanılarak Dağlık Bölgelerde Uygulaması ve Erzurum Kırkgöze Havzası Örneği. (PhD), Atatürk Üniversitesi, Fen Bilimleri Enstitüsü, Erzurum, Türkiye.

Shirinian-Orlando, A. A., \& Uchrin, C. G. (2007). Modeling the hydrology and water quality using BASINS/HSPF for the upper Maurice River watershed, New Jersey. Journal of Environmental Science and Health, Part A, 42(3), 289-303.

Singh, P., \& Singh, V. P. (2001). Snow and Glacier Hydrology (Vol. 3). Netherlands: Kluwer Academic Publishers. 
Şorman, A. (2004). Importance of Hydro-Meteorological Data Bank for Use in Coupled Models and Disaster Management Using New Techniques (RS/GIS) in Turkey: EFCA.

Tzoraki, O., \& Nikolaidis, N. P. (2007). A generalized framework for modeling the hydrologic and biogeochemical response of a Mediterranean temporary river basin. Journal of Hydrology, 346(3-4), 112-121.

Yilmaz, A. G., \& Imteaz, M. A. (2011). Impact of climate change on runoff in the upper part of the Euphrates basin. Hydrological Sciences Journal-Journal Des Sciences Hydrologiques, 56(7), 1265-1279. doi:10.1080/02626667.2011.609173

Yucel, I., Guventurk, A., \& Sen, O. L. (2015). Climate change impacts on snowmelt runoff for mountainous transboundary basins in eastern Turkey. International Journal of Climatology, 35(2), 215-228. doi:10.1002/joc.3974 